


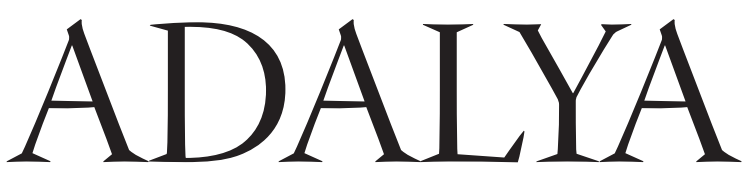

The Annual of the Koç University Suna \& İnan Kıraç Research Center for Mediterranean Civilizations

(OFFPRINT) 


\section{ADALYA}

The Annual of the Koç University Suna \& İnan Kıraç Research Center for Mediterranean Civilizations (AKMED)

Mode of publication

Adalya, a peer reviewed publication, is indexed in the A\&HCI

(Arts \& Humanities Citation Index) and CC/A\&H (Current Contents / Arts \& Humanities)

Adalya is also indexed in the Social Sciences and Humanities Database of TÜBİTAK/ULAKBIM TR index and EBSCO.

Publisher certificate number

Worldwide periodical

18318

ISSN 1301-2746

Publisher management

Koç University

Rumelifeneri Yolu, 34450 Sariyer / İstanbul

Publisher Umran Savaș İnan, President, on behalf of Koç University

Editor-in-chief Oğuz Tekin

Editors Tarkan Kahya and Arif Yacı

English copyediting Mark Wilson

Editorial Advisory Board (Members serve for a period of five years)

Prof. Dr. Mustafa Adak, Akdeniz University (2018-2022)

Prof. Dr. Engin Akyürek, Koç University (2018-2022)

Prof. Dr. Nicholas D. Cahill, University of Wisconsin-Madison (2018-2022)

Prof. Dr. Edhem Eldem, Boğaziçi University / Collège de France (2018-2022)

Prof. Dr. Mehmet Özdoğan, Emeritus, Istanbul University (2016-2020)

Prof. Dr. C. Brian Rose, University of Pennsylvania (2018-2022)

Prof. Dr. Charlotte Roueché, Emerita, King's College London (2019-2023)

Prof. Dr. Christof Schuler, DAI München (2017-2021)

Prof. Dr. R. R. R. Smith, University of Oxford (2016-2020)

(c) Koç University AKMED, 2020

Production Zero Production Ltd.

Abdullah Sok. No. 17 Taksim 34433 İstanbul

Tel: +90 (212) 2447521 • Fax: +90 (212) 2443209

info@zerobooksonline.com; www.zerobooksonline.com

Printing Fotokitap Fotoğraf Ürünleri Paz. ve Tic. Ltd. Şti.

Oruç Reis Mah. Tekstilkent B-5 Blok No: 10-AH111

Esenler - İstanbul / Turkey

Certificate number: 47448

Mailing address

Barbaros Mah. Kocatepe Sok. No. 22

Kaleiçi 07100 Antalya - TURKEY

Tel: +90 (242) 24342 74 • Fax: +90 (242) 2438013

https://akmed.ku.edu.tr

E-mail address $\quad$ adalya@ku.edu.tr 


\section{Contents}

Burçin Erdoğu

Capturing the Seen and Unseen in the Beldibi Rock Art .. 1

Özlem Çevik - Murat Dirican - Aydın Ulubey - Osman Vuruşkan

The Galena Objects from Neolithic Ulucak: The Earliest Metallic Finds in Western Turkey 7

Abdullah Hacar - K. Aslıhan Yener

Anatolian Pot Marks in the 3rd Millennium BC: Signage, Early State Formation, and

Organization of Production 25

A. Tuba Ökse

Reflection on the Sunrise Positions in Early and Middle Bronze Age Extramural

Cemeteries in Anatolia 59

Sevgül Çilingir Cesur

The Timing of Ritual Performance in Hittite Texts: The "Morning" Rites 87

Dries Daems

Reassessing the Origin of Polis in Lycia and Southwest Anatolia 111

Fatma Şahin - Erkan Alkaç

Banded Bowls from Tepebağ Höyük (Cilicia Pedias)

Özgün Kasar - Kaan İren

Leaded Bronze Arrowheads at Daskyleion 175

Hazar Kaba

An Elite Tomb from Soloi: New Evidence for the Funerary Archaeology of Cyprus

Erkan Alkaç - Ulus Tepebaş

The Gem Stamp on the Handle of a Mushroom-rimmed Amphora from Knidos:

An Assessment of the Centauromachy in Terms of Stamps and Iconography

Hüseyin Sami Öztürk - Ögül Emre Öncü

Olympos in Lycia: A Novel Assessment of its History and Localization in Light of Recent

Archaeological and Epigraphical Research

Nihal Tüner Önen

Two New Inscriptions from the Claudian Period at Perge 277

Handegül Canlı

A Unique Roman Folding Knife Handle with Eagle Ornament from Philadelphia in Cilicia 289 
Şenkal Kileci - Birol Can

A New Honorific Inscription from Blaundos: Tiberius Claudius Lucius, the Priest of

Dionysos Kathegemon

Ahmet Tolga Tek - Hacer Sancaktar

A Numismatic Riddle from Arykanda: The God of the Water Spring .

Mark Wilson

The Discovery of a Menorah in Attalia (Kaleiçi, Antalya) and its Significance for

Jewish Communities in Pamphylia

Özgü Çömezoğlu Uzbek

A North African Plate Unearthed in the Andriake Excavations

Philip Bes

Early Byzantine Pottery from Limyra's West and East Gate Excavations

Nilgün Elam

Ecclesiastical Personages of Side ( $\Sigma i \delta \eta$ ) of Pamphylia according to Literary and Sphragistic Data

Ömür Bakırer

Window Glass from the Excavations in the Seljuk Palace at Alanya

Mahmut Demir - Terrance Michael Patrick Duggan - Erkan Kurul

Observations and Assessments of Some Epigraphic Graffiti Found on Entrances in

Kaleiçi/Antalya

Ayşe Ozil

A Traveller in One's Homeland: Local Interest in Archaeology and Travel Writing in the

Ottoman Greek World in 19th Century Anatolia

Alex Rodriguez Suarez

Two Church Bells from Antalya: Traces of the Religious Soundscape of the Late Ottoman Period 517 


\title{
The Timing of Ritual Performance in Hittite Texts: The "Morning" Rites
}

\author{
SEVGÜL ÇILINGIR CESUR*
}

\begin{abstract}
Hittite rituals can be defined as religious practices that are meant to activate supernatural powers for the sake of a human being. These systematic practices were enacted under the supervision of ritual practitioners in case of any negative situations namely illness, black magic, epidemic and evil. Considering Hittite texts, it is noticeable that a ritual was carried out on any day of the year on the request of the ritual patron. Although there is not a pre-determined time for performing a ritual, it is intrinsic for these religious practices that they have their own sense of time. Furthermore, the concepts of time are applied in an extremely systematic fashion and "ritual time" is a phenomenon, which plays an important role in regulating the course of the rites. Although the perception of time in Hittite rituals has been previously studied, there is not yet any systematic research focusing merely on the morning period. Therefore, this article aims at contributing the significance of time by investigating Hittite magical ritual texts with regard to the terms used for the morning period and the typical rites performed in that part of the day by comparing the data obtained from ritual texts listed under CTH 390-500.
\end{abstract}

Keywords: Hittites, ancient Anatolia, religion, magic, ritual, morning

\section{Öz}

Hitit insanı içinde yaşadığı dünyayı anlamlandırmak, başta hastalık olmak üzere olumsuz bir durum, salgın ya da kara büyü gibi çeşitli güçlüklere çözüm bulmak ve tanrilarla iletişim kurmak için ritüellere başvurur. Çivi yazılı ritüel metinleri geniş malzeme grubu ve büyü uygulamaları ile araştırmacılara farklı açılardan pek çok veri sunar. Bu alanda günümüze kadar yapilan çalışmalar genellikle ritüellerin amacı ve ortaya çıktıkları coğrafi bölgelere odaklanır. Bu çalışma ise çivi yazılı ritüel metinlerinde geçen zaman kavramlarını incelemeyi amaçlamaktadır. Hitit büyü ritüellerinin (CTH 390-500) bayram kutlamaları gibi önceden belirlenmiş bir zamanı yoktur. Ritüele duyulan ihtiyaç onun icra edilmesi için yeterlidir. Bu makale, bir takvimi olmamasına rağmen Hitit büyü ritüellerinin bir zaman algısı olduğunu ortaya koymuştur. Dahası metinlerin önemli bir kısmında çeşitli ritüel uygulamalarının günün hangi bölümünde yapıldıkları da açıkça belirtilmiştir. Bu bilgilerden yola çıkarak, güneşin doğuşundan öğlene kadar devam eden zaman dilimleri için Hitit ritüel metinlerinde geçen kavramların filolojik incelemesi yapılmış ve bu zaman dilimlerinde icra edilen tipik ritüel davranışları ele alınmıştır. Böylece Hitit toplumunun ritüel aracilığıla sabah vaktine atfettiğgi anlamlar tespit edilmeye çalışılmıştır.

Anahtar Kelimeler: Hititler, eski Anadolu, din, ritüel, büyü, sabah

* Dr. Sevgül Çilingir Cesur, Ege Üniversitesi, Çeşme Turizm Fakültesi, Turizm Rehberliği Bölümü, 35930 İzmir, Türkiye. E-mail: sevgul.cilingir.cesur@ege.edu.tr ; https://orcid.org/0000-0001-6943-7153

This article was written as part of the project "The Concepts of Time and Temporality in Hittite Rituals (CTH 390500)", which was supported by the Post-Doctorate Research Fellowship Program (BIDEB 2219/A) of TÜBİTAK. The research was completed at Würzburg University and included short-term research stays at the Hethitologie-Archiv of the Akademie der Wissenschaften und der Literatur Mainz. I would like to thank Daniel Schwemer for his valuable comments on the original manuscript at its various stages. I am also grateful to James Burgin for his corrections and suggestions, and also to Michele Cammarosano for his contributing comments. The abbreviations in this article follow those used by the Hittite Dictionary of the Oriental Institute of the University of Chicago (CHD). 


\section{Introduction}

Several studies have revealed that rituals play an essential role in Hittite religion by constituting an important part of religious life. ${ }^{1}$ As is well known, the Hittite texts justly treated in different sections of the Catalogue des Textes Hittites $(\mathrm{CTH})^{2}$ by E. Laroche give witness to two main categories of rituals. The first category comprises the festivals $\left(\mathrm{EZEN}_{4}\right)$ prescribed in the official calendar, which consist of the rites performed at regular intervals with the aim of stimulating the satisfaction of the deities for the well-being of the Hittite society. The second consists of the magical rituals (SISKUR), which mostly intend to neutralize the negative situations such as an illness, epidemic, plague, black magic or any other negative phenomena. In contrast to the festival rites, the magical rituals are not dependent on the cultic calendar; rather, they are enacted on a case-by-case basis in specific situations. However, does it mean that they do not have any sense of time?

Hittite magical rituals have long been recognized as a group of texts that are not only wellorganized but also offer detailed information about the materials required as well as the rites to be carried out. Especially in the case of well-preserved tablets, most details and individual steps of the ritual performance can be identified. The first and second paragraphs of each text usually mention the name of the ritual practitioner together with his or her native land, the purpose of the ritual, and a list of the ritual paraphernalia. The rest of the text specifies the rites to be performed. ${ }^{3}$ When the texts are scrutinized, it is also possible to single out two aspects that regulate the course of the rites: these are "ritual space" 4 and "ritual time".

The phrase mebur UL kuitki tukkari "the time does not matter" appears in a Middle Hittite substitution ritual for the Great King Tuthaliya, ${ }^{5}$ one of the rare magical ritual texts in the Hittite corpus in which the time of the rites is explicitly said to be insignificant. ${ }^{6}$ On the contrary, Hittite rituals usually specify which rites will be performed during which part of the day. A closer look at the concepts of time enables us not only to gain a better understanding of the terminology for various parts of the day, but also to identify specific rites performed at certain times and to describe how the cycle of the day structured the practices in magical rituals.

Although the subject has been previously studied, there is not any systematic research focusing specifically on the concept of morning in the texts. In his doctoral dissertation D.H. Engelhard indicates that time is an essential component in Hittite rituals by discussing the

1 Ünal 1988, 52-85; Beckman 1989, 102-6; Haas 1994, 674-92, 876-906; Güterbock 1997, 87-90; Haas 2003, 26-48; Bawanypeck 2005, 11-15.

2 For the updated version see S. Košak-G.G.W. Müller-S. Görke-Ch. Steitler, hethiter.net/: Catalog (2020-01-27).

3 See also Trémouille 2004, 157-203.

4 Cf. Haas 1994, 907-8; Engelhard 1970, 182-202. There is yet no detailed comprehensive study on the concepts of space in Hittite magical rituals.

5 CTH 448.4.1.a.D; KUB 12.16 5'. For the translation of the text, see Taracha 2000, 34. For detailed information about the etymology of tukkāri, see Neu 1968, 178-80. For the etymology of the verb tukk-, see Joseph 1988, 205-13. McMahon points out that the verb has the meaning of "to be prescribed, specified"; see McMahon 1991, 258-59.

6 There is another example of tukk-together with mebur in a text of the festival for renewing the ${ }^{\mathrm{Kuš}} k u r s ̌ a$-hunting bag of the Tutelary Deity (CTH 683): ${ }^{(1)}\left[\right.$ ma-a-an $\check{S} A$ ? ] ${ }^{\mathrm{D}}$ Zi-it-ba-ri-ia $\check{U}^{\mathrm{D}} \mathrm{LAMMA}$ Ha-te-en-zu-wa ${ }^{(2)}\left[2{ }^{\mathrm{K}}\right]^{\mathrm{US}} \mathrm{kur}$ - $\breve{s} u-u \check{s}$

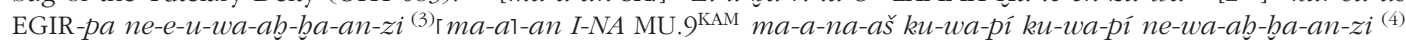
me-bur U-UL tu-uk-ka-a-ri "[When] they renew the [two] hunting bags [of] Zithariya and of the Tutelary Deity of Hatenzuwa - whether they renew them in the ninth year or whenever, the time does not matter" (KUB 55.43 obv. I 1-4); see McMahon 1991, 144-45; Groddek 2002a, 73-79. Cf. also the Cultic Festival of Istanuwa (CTH 772.3.A): meb̧ur UL kuitki tukkāri (KUB 32.123 rev. III 14); see Starke 1985, 309. 
ritual actions in two groups: those performed during the daytime and those at night respectively. However, his work does not provide detailed information about the terminology and only summarizes the specific ritual practices that are attested to be performed during the day or at night. ${ }^{7}$ In his book on Hittite religion, V. Haas also briefly explains that the Hittites chose the suitable time for the magical rituals carefully and that the rites were usually performed during sunrise/dawn and sunset/dusk. ${ }^{8}$ A. Mouton demonstrates that there are some ritual actions that are usually performed at night. ${ }^{9}$ CHD L-N offers a broad analysis of the terminology for morning in Hittite texts (CHD L-N: 74-79). The aim of the present study is to evaluate the concepts of time related to the morning period in more detail, both with regard to the terminology employed in Hittite magical rituals and the typical rites performed.

\section{Terms for "Morning" in Hittite Rituals}

The Hittites perceived the day to be structured in seven parts: dawn, morning, daytime/noon, afternoon/meal time, evening, sunset and night. ${ }^{10}$ In ritual texts, there are two ways of referring to the "morning". On the one hand, terms such as karuwariwar, which signifies dawn, and luk(k)atta, which means both dawn and morning, may be used. On the other hand, various phrases describing the position and motion of the sun are employed. The morning period starts with karuwariwar, a term generally translated as "at dawn, early in the morning". Following dawn, the morning, which also comprises dawn, is designated generally as $l u k(k)$ $a t t a / i$. The two terms karuwariwar and $l u k(k) a t t a / i$ can be placed in juxtaposition in phrases such as mān lukkatta karuwariwar "when it becomes light at dawn" and lukkatta=ma INA UD.X.KAM karuwariwar "but in the morning on the Xth day at dawn". ${ }^{11}$ Moreover, it is likely that various phrases are combined with lukkatta/i in order to indicate subdivisions within the morning period. These include mān/mab̧ban luk(k)atta/GIM-an lukzi "when it becomes light", mān lukkatta DUTU-uš näwi upzi "when it becomes light (but) the sun has not risen yet", mān lukkatta DUTU-uš upzi "when it becomes light (and) the sun rises", and lukkatta=ma=kan kuitman DUTU-uš nāwi uizzi "but on the (following) morning when the sun has not risen yet". Finally, apart from the direct designations, it is possible to refer to the morning by using the Sumerogram DUTU "the sun", even with or without other specific time indicators, e.g. DUTU-

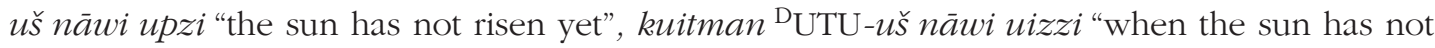

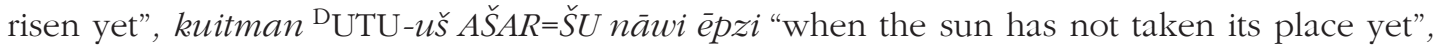
and DUTU-uš upzi "the sun rises".

\section{karuwariwar and forms of luk-}

Friedrich and Tischler translate karuwariwar as "Morgen" (HW: 104; HEG I-K: 530). Tischler also asserted that it corresponds with Akkadian šêru, which denotes "morning star, dawn, morning" (HEG I-K: 530; CAD Š/II: 331). Puhvel translates karuwariwar as "at daybreak, early in the morning, (in) the act of spending the daybreak, (at) the time of being up at dawn" while

\footnotetext{
7 Engelhard 1970, 202-10.

8 Haas 1994, 691, 906-7.

9 Mouton 2008a, 1-17.

10 See Engelhard 1970, 202-10; Mouton 2008a, 1-17. For a significant analysis of the Hittite perception of time, see Beckman 2017, 248-50.

11 There are only two rituals in which karuwariwar is attested alone. These are the ritual of Paškuwatti against effeminacy (CTH 406; KUB 7.5 obv. II 20'-26') and the purification ritual of a house (CTH 446.A; KUB 7.41 obv. I 4).
} 
agreeing with Tischler's assertion that šêru is an Akkadian equivalent of Hittite karuwariwar (HED 4/K: 86-87). Etymologically, Oettinger suggests that karuwariwar is originally an adverb formed by the verbal substantive ari(ya)war "das Aufstehen" and karü "früh" meaning "das früh Aufstehen". ${ }^{12}$ With regard to the attested variants of karuwariwar, Kloekhorst follows Puhvel in arguing that the form karuwariwar is a secondary reshaping based on the simplex karū, whereas kariwariwar or karewariwar represents the original form of the adverb. ${ }^{13}$

The terms $l u k(k) a t, l u k(k) a t t a($ all.), $l u k(k) a t(t) i$ (dat.-loc.) are all derived from the verb $l u k-$ "to grow bright, dawn". ${ }^{14}$ Friedrich translated the term as "am nächsten Morgen, am folgenden Tage" (HW: 130). Kammenhuber interpreted luk(k)- "tagen" and luk(k)atta as an adverb "am (nächsten) Morgen". ${ }^{15}$ Kümmel suggested that act. pres. sg. 3 lukzi should be translated as "es wird hell", whereas the middle form luk(k)atta rather means "es ist hell", and also includes sunrise. ${ }^{16}$ Tischler interpreted it as "hell werden, tagen" (HEG L-M: 65-69). Puhvel, on the other hand, suggests "(day)light, daybreak, dawn, morning; the morrow, the next day" and remarks that there is no need for being too restrictive in translating this term (HED 5/L: 108-111). According to CHD L-N, "the verb luk- is confined to describing the faint but growing sunlight in the atmosphere at dawn just before the sun rises". Nevertheless, if mid. pres. sg. $3 l u k(k)$ $a t t a / i$ is used simply to start the rites of a new day off from those of the preceding day, it can simply be translated as "on the morrow, on the following day" (CHD L-N: 74-77). The fact that $l u k(k) a t t a$ is rarely used alone in Hittite rituals supports the idea that the term became a general descriptor for the (following) morning, and that there was often a need to specify the time by adding other more specific time expressions.

Examination of the evidence from Hittite ritual texts allows one to infer that if a specific subdivision of the morning is emphasized, the term $l u k(k) a t t a / i$ is used together with the temporal conjunctions such as mān, mab̧han and GIM-an, which makes the time more explicit. Denoting "when, whenever, as soon as", these temporal conjunctions describe the process of sunrise in the sense of "when it becomes light, when it dawns". They are commonly used with mid. pres. sg. $3 l u k(k) a t t a$ in Hittite rituals, except for GIM-an, which is consistently used with act. pres. sg. 3 lukzi. ${ }^{17}$ The Hittite ritual texts also illustrate $l u k(k) a t t a / i$ in juxtaposition with the temporal adverb karuwariwar, which refers to more specific periods of time early in the morning. In the context of rituals, it seems that this type of usage refers to the time between dawn and sunrise. The fleeting nature of ritual performances during this period is emphasized in some rituals by the adverb budak, which denotes "straightway, at once, promptly, quickly" (HED 3/H: 414-416). The promptness of the ritual action indicated by budak makes it clear that the action of these rituals is to take place in the narrow, half-hour window between the onset of dawn and daybreak.

12 Oettinger 1979, 479; cf. also Neu's translation of karuwariwar with "beim Erwachen Auf-Stehen/Sich-Erheben" in Neu 1980, 46.

13 Kloekhorst 2008, 447-48.

14 For a detailed discussion on the term, see Neu 1980, 16-19.

15 See Kammenhuber 1961, 336.

16 See Kümmel 1967, 33; cf. also Carruba 1980, 363-64; Stefanini 1983, 148-49.

17 In a substitution ritual for the king (CTH 419.A) the two morning expressions luk(k)atta and GIM-an lukzi are mentioned successively: ${ }^{(28)} \mathrm{GIM}-a n-m a$ lu-uk-zi nu-za LUGAL-uš UGU ap-pa-tar DÙ-zi [EGIR-an]-da-ma-az pár$n a-a s ̌$ KIN-ur ${ }^{(59)} p a ́ r-k u-u-i$ KIN-ur DÙ-zi lu-uk-kat-ti-ma-za LUGAL-uš SISKUR [ ba-la-le-è-i] n-zi DÙ-zi (KUB 24.5 obv. 28-29); see Kümmel 1967, 7-13; Trabazo 2010, 38-39. Kümmel argues that luk(k)atta should be understood here as temporally consecutive to GIM-an lukzi, which indicates an earlier part of the morning; see Kümmel $1967,32$. 
Furthermore, a variation of the word pattern mān lukkatta ... karuwariwar ... MUL HI.A nuwa aranda "when it becomes light ... at dawn ... when the stars still stand" is found in a group of rituals for the expansion of the cult of the Deity of the Night. ${ }^{18}$ This signifies a period when the sky has started to illuminate, but it is still possible to see the stars, namely the early dawn. Here too the promptness of the ritual action is emphasized by adding budak.

Another description of one of the subdivisions in the morning is formed with a negated form of the verb $l u k$ - in a fragment of a purification ritual. The text contains the word pattern mab̧ban=ma $\mathrm{GE}_{6}$-anza lukzi ${ }^{\mathrm{MUL}} \mathrm{UD}$.ZAL.LE=kan uizzi lukzi nāwi "But when the night grows brighter and the morning star rises, (while) it has not yet become light". Here again, the ritual patron has to act promptly (budak). ${ }^{19}$ Almost all significant features of the time period that we would call early dawn are extant in this text: the process of the initial illumination of the night, the visibility of the morning star, and the absence of the sun in the sky. Although the word karuwariwar is not used here, the text clearly refers to the same time period as the expression mān lukkatta ... karuwariwar ... MUL ${ }^{\text {HI.A }}$ nuwa aranda.

There is a single example where karuwariwar occurs with budak but without luk(k)atta. This text belongs to a group of purification rites, and the second paragraph informs us that the entire city - the men, women and children - wash themselves, and then sleep while the ritual practitioner performs on the third day. With reference to this third day, it is written down

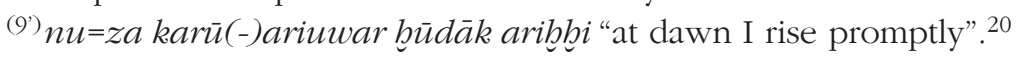

In sum, there are five different phrases formed with $l u k(k)$ atta and/or karuwariwar in Hittite ritual texts: (i) $m \bar{a} n / m a b g h a n l u k(k) a t t a$ or GIM-an lukzi corresponding to the process of lightening of the sky; (ii) lukkatta ... karuwariwar, which possibly refers to the period between dawn and sunrise; (iii) mān lukkatta ... karuwariwar with the adverb budāk emphasizing the promptness required of the ritual action, which is probably enacted between the late dawn and sunrise; (iv) karuwariwar, alone but with an emphasis too on the quick manner of the ritual action expressed by budāk, probably corresponding to the late dawn again; (v) mān lukkatta ... karuwariwar ... MUL ${ }^{\mathrm{HI} . \mathrm{A}}$ nuwa aranda and mab̧han=ma $\mathrm{GE}_{6}$-anza lukzi ${ }^{\mathrm{MUL}} \mathrm{UD}$. ZAL.LE-kan uizzi lukzi nāwi corresponding possibly to the early dawn. Regarding the terms above, only the phrases mān/mab̧ban luk(k)atta and GIM-an lukzi may comprise the sunrise without mentioning the sun 'DUTU' itself, while the remainder seems to refer to the dawn, i.e. the period before the sun becomes visible on the horizon.

\section{Designations for "Morning" Referencing the Sun}

The sun has always held a fundamental role in human life by passing through the sky every day, by providing light and warmth, and also by witnessing and marking out the pace of daily life. Hittite society was no different. The sun was deified, and the solar deity stood at the

18 CTH 481.A; ${ }^{(14)}$ I-NA UD. $3^{\mathrm{KAM}_{-}-m a}$ ma-a-an lu-uk-kat-ta nu EN.SÍSKUR ka-ru-ú-a-ri-wa-ar ${ }^{(15)} b u-u$-da-ak I-NA É.DINGIR ${ }^{L I M} \bar{u}^{\prime}-i z-z i$ MUL ${ }^{\mathrm{HI}} \mathrm{A}$ I $n u-u-a$ a-ra-an-da "Then on the morrow of the third day, the ritual patron comes immediately at dawn into the temple, (when) the stars are still out (lit. 'stand')." (KUB 29.4 + KBo 24.86 obv. II 1415); see Miller 2004, 281.

19 CTH 456.1.A; ${ }^{\left(16^{\prime}\right)} m a-a b-b g a-a n-m a^{\left({ }^{\prime} 7^{\prime}\right)} \mathrm{GE}_{6}-a n-z a$ lu-uk-zi MULUD.ZAL.LE-kán ú-iz-zi lu-** $u k^{*}-z i$ na-a-ú-i ${ }^{\left(18^{\prime}\right)} n a-a s_{-}-$

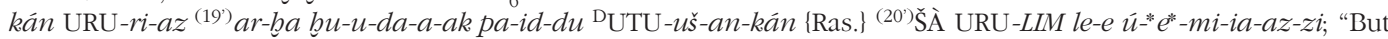
when the night grows brighter and the morning star rises, (while) it has not yet become light, let him promptly leave the city; the sun must not find him inside the city!" (KBo 12.103, obv. II 16'-18'); see Kümmel 1967, 32-33; CHD L-N, 75; F. Fuscagni (ed.), hethiter.net/: CTH 456.1 (INTR 2015-12-21).

20 CTH 456.9; see Torri and Barsacchi 2018, 113; F. Fuscagni (ed.), hethiter.net/: CTH 456.9 (INTR 2016-03-22). 
highest rank of the state pantheon together with the Storm-god as essential to the conditions of life. This is clearly narrated in the myth of the disappearance of the Sun-god. ${ }^{21}$ It should come as no surprise, then, that the ritual texts also refer to the position and motion of the sun to describe the different phases of the morning period. Most often written with the Sumerogram ${ }^{\mathrm{D}} \mathrm{UTU}^{22}$, the sun appears not only in accordance with different temporal conjunctions such as màn and kuitman, but also with the term $l u k(k) a t t a$. The verbs uwa- "to come", up- "to rise", and $e p$ - "to take" are also used to signify the motions of the sun. In the context of rituals, temporal phrases formed with the sun supply definite information about a specific period of the day rather than addressing the general phases.

The first example from this group is màn lukkatta DUTU-uš nāwi uizzi "when it becomes light (but) the sun has not risen yet". ${ }^{23}$ Considering the ritual texts, it is probable that this pattern is another way of expressing dawn before sunrise. Secondly, there are also phrases that indicate the point of sunrise exactly such as mān lukkatta ${ }^{\mathrm{D} U T U}-u s ̌ u p z i$ "when it becomes light (and) the sun rises" appearing in the ritual of Ammihatna against impurity ${ }^{24}$ or lukkatta $=m a=k a n{ }^{\mathrm{D} U T U}-u s ̌$ upzi "but on the (following) morning (when) the sun rises" in the ritual of Wattiti. ${ }^{25}$ Finally, the phrase kuitman ${ }^{\mathrm{D} U T U}-u \check{S} A \check{S} A R-\check{S} U$ nāwi èpzi "when the sun has not taken its place yet" is usually interpreted as referring to dawn. ${ }^{26}$ However, the possibility should be kept in mind that the phrase could also address to the period before the sun reaches the highest point in the sky since we do not know the Hittite perception about the exact place of the sun.

Hittite rituals provide limited information about midday when compared to the terminology on morning. Although it is widely accepted that the primary times for ritual actions are morning and nighttime, ${ }^{27}$ it is also possible to encounter phrases describing midday. The first example of these phrases is UD ${ }^{\mathrm{HI} . \mathrm{A}}-$ ti ištarna pedi, which is translated by Puhvel as "on the day at mid-point" (HED 2/E-I: 480-481). ${ }^{28}$ There is, to my knowledge, only one ritual that concretely mentions the midday using this phrase. In the ritual of Paškuwatti, midday is one of the three cycles in a day during which the goddess Uliliyaš ${ }^{29}$ is entreated. ${ }^{30}$ Hoffner argues that

21 CTH 323 "The Myth of the Disappearance and Return of the Sun-god". See Daddi and Polvani 1990, 57-71; Hoffner 1998, 27-28; Haas 2006, 117-20; Groddek 2002b, 119-31. For the commentary and enhanced bibliography of the text, see also Steitler 2017, 207-10.

22 The recent book by Steitler has argued that many specific solar deities were worshiped in Anatolia during the Bronze Age. One of the designations for the solar deity in the Hittite texts is Sumerian ${ }^{D} U T U$. Steitler argues that scholars mostly recognize ${ }^{\mathrm{D} U T U}$ as "Istanu" in Hittite, thanks to the phonetic complements of the $u$-stem. Nevertheless, he considers Ištanu as a Hittite generic name referring to any solar deity; see Steitler 2017, 13-17, especially nn. 31 and 42 .

23 Cf. also the translation by Siegelová 1986, 314; Collins 1990, 222; Bawanypeck 2005, 277.

24 CTH 471.A; KBo 5.2 obv. II 29; cf. Strauß 2006, 237.

25 Cf. also the translation of Fuscagni in F. Fuscagni (ed.), hethiter.net/: CTH 390 (INTR 2017-03-06).

26 This phrase appears only in the ritual of Ammihatna against impurity (CTH 471; KBo 5.2 obv. I 42); cf. Strauß 2006, 235.

27 Engelhard 1970, 210; Haas 1994, 906; Mouton 2008a, 1-17.

28 Cf. Hoffner 1987, 278; Trabazo 2002, 461; Mouton 2007, 139

29 Friedrich translated the word as "Grün(?), Pflanzenwuchs(?)" (HW, 233). Recent studies have argued that ulili-is a word interpreted as "field". When applied with the Luwian possessive suffix (genitival adjective) -ašš $i$, it is widely accepted as a Luwian counterpart of the Hurrian Šaušga of the countryside written as DIŠTAR LÍL; see Wegner 1981, 31; Taracha 2009, 116. For comments on the goddess Uliliyaši in the ritual of Paškuwatti, see Hoffner 1987, 281.

30 CTH 406.A ${ }_{3}$; KUB 7.5 obv. II 22'. Ibid. 26' (ištarna UD.KAM ${ }^{\mathrm{HI}} \cdot \mathrm{A}-t i$ "at mid-day"). Both lines use the plural form for UD.KAM, which is unexpected in this text. Hoffner claims that the Hittite complement $-t i$ indicates the locative 
the threefold breaking of bread signifies the three meal times in that ritual. ${ }^{31}$ Another expression indicating noon is UD-az ištarna paizzi. Lebrun translates the sentence as "Au petit matin, une journée va s'écouler". ${ }^{32}$ Friedrich states that ištarna with the verb pai- denotes "(dazwischen) vergehen (von der Zeit)" (HW: 154). Strauß interprets the sentence as "der Tag vergeht inzwischen" by referring to Friedrich's translation. ${ }^{33}$ Mouton, on the other hand, interprets it as "Ce jour-là passe pendant ce temps". ${ }^{44}$ CHD L-N translates it as "the day reaches its midpoint (noon?)" (CHD L-N: 77a). In Hittite rituals, there are two texts referring to this phrase: the first is the birth ritual of Papanegri from Kummanni, ${ }^{35}$ while the second is the ritual of Ammihatna, Tulbi and Mati against an impurity in the temple of the god. ${ }^{36}$ The latter qualifies UD-az $i s ̌ t a r n a ~ p a i z z i$ with $l u k(k) a t t a$, supporting the idea that $l u k(k) a t t a$ is the common name for the (following) morning. The pattern UD-az ištarna paizzi serves for referring to a more specific time at morning. Therefore, luk(k)atta ... UD-az ištarna paizzi should be translated as "on the (following) morning ... (when) the day reaches its midpoint".

\section{The Typical Rites of Morning}

The Hittite ritual texts tend to put general information on the content and context of the ritual in the very first and second paragraphs. One would thus also expect to encounter the time period of the ritual in this section. On the contrary, most of the ritual texts do not mention any time patterns at the beginning. Expressions of time mostly appear within the running instructions of action emphasizing that the perception of time is strictly bound up with the ritual action. Therefore, it is possible to identify certain ritual practices that are usually performed in the morning. In the light of the texts, it can be claimed that morning is a period of (i) rites of separation instantiated mostly by cutting off or disentangling the threads of wool, (ii) rites of washing and purification, and (iii) invocation offerings for the deities. The principal verbs that are used in defining these rites are arba tubš- "to cut off" and partai- "to separate" for the separation rites; warnu- "to wash" for the purification rites; and šipant- "to offer" and dai- "to put" in the offering ceremonies for invoking the deities. In addition, the Sumerogram DÙ "to perform" is used for some special rites, and penna- "to drive (there)", unna- "to drive (towards)", uwa- "to come", ${ }^{37}$ and pai- "to go" are used to indicate the change of the ritual place in the morning.

singular šiwatti. Therefore, he proposes an emendation to UD.KAM!-ti in both lines since there is no need for the plural HुI.A.; see Hoffner 1987, 287. Although Mouton prefers emending the plural HुI.A both for UD.KAM-ti ištarna pedi and ištarna UD.KAM-ti, she uses the plural HÁ in her transliteration; see Mouton 2007, 133.

31 Hoffner 1987, 286. See also Mouton 2007, 139 and Trabazo 2002, 461 n. 50.

32 Lebrun 1979, 139-64.

33 Strauß 2006, 267.

34 Mouton 2016, 263.

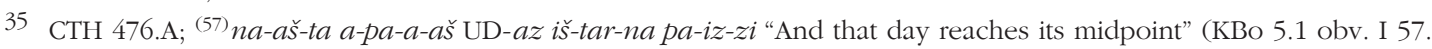
See Strauß 2006, 288 and Mouton 2016, 262-63.

36 CTH 472.A/B; ${ }^{58}[l u-u k]-k a t-t i-m a-k a ́ n$ UD-[az iš $]$-tar-na pa-iz-[zi] ${ }^{(59)}[n u$ še-bui-il-li-ia] ú-e-da-ar da-an-[zi] "But [on the (following) mor]ning - when the day reach[es] its midpoint - [and] they ta[ke] the water [of purification.]" (KUB 30.38 + KBo 23.1 obv. 58); see Strauß 2006, 262-67.

37 With inf. karpuwanzi (karp-) "come to take". 


\section{Separation Rite in the Morning}

As discussed by Haas, the magical practices of the Hittites usually set up an explicit contrast between positive and negative phenomenon. ${ }^{38}$ The underlying premise is that whatever causes the unfavorable situation to occur can be turned into positive or counteracted by means of magical practices. This contrast is mostly evidenced in the ritual practices of binding and separation. After the chthonic darkness of the preceding night during which the binding rite is applied, the sky is enlightened by the sun in the morning. This makes possible the freeing from negative situations like black magic, impurity, sin and illness by means of severing the previously applied bonds. The main materials of these rites are threads of wool having different colors. The binding is usually undertaken with the verb $\operatorname{bam}(m) a(n) k / h a m(m) e n k-$ "to tie" and serves to transmit the unfavorable situation of the patient onto the ritual paraphernalia. ${ }^{39}$ The next morning, the separation is enacted, usually expressed with arbsa tubš - "to cut off" in order to take the evil away and help ensure the purified state of the ritual patron.

A good example of a separation rite is found in the ritual of Anniwiyani for the tutelary deities. There the ritual patron is bound ( $\operatorname{bam}(m) a(n) k$-) with threads of red and blue wool to the four bedposts when night falls ( nu mab̧ban nekuzi). After also binding his chariot, bow and quiver, the ritual paraphernalia is put into a basket and placed under his bed. The ritual patron spends the whole night with these paraphernalia, and when it becomes light (mān lukkatta), the threads of wool are cut off. ${ }^{40}$

A similar set of ritual actions is found in the ritual of the augur Huwarlu against evil bird omens. The augur performs this ritual in cooperation with an Old Woman. According to the text, the Old Woman ties ( $\operatorname{bam}(m) a(n) k-)$ red wool to the king and queen, to the four corners of the palace, to the threshold of the gate, and to the bolt. Then the king and the queen sleep inside during the night along with the ritual paraphernalia. When it becomes light ( mabyann=a lukkatta), the Old Woman cuts off the threads of wool and places them into the basket. $^{41}$

A third example of separation rites performed at morning comes from the ritual of Alli against bewitchment. As stated, after giving offerings outside to Marwaya ${ }^{42}$ miyanit-tongue, ${ }^{43}$ the Dark Earth, the Sun-god, Ariya,${ }^{44}$ and lastly Šalawaneš of the Gate, ${ }^{45}$ Alli returns to the city

38 Haas 1990, 235.

39 Szabó remarks that the binding rite is usually seen in Luwian-Hittite rituals; see Szabó 1971, 95-102.

40 CTH 393.A; ${ }^{(22)}$ ma-a-an lu-uk-kat-ta na-aš-ta A-NA EN SÍSKUR ${ }^{(23)} b u$-u-ma-an-da-zi-ia SÍG a-an-ta-ra-an SÍG mida-an-na ${ }^{(24)} a r-b ु a ~ t u ́ b-s ̌ a-a n-z i ~ n a-a t-s ̌ a-a n ~ k a t-t a ~ p a ́ d-d a-n i-i{ }^{(25)} d a-a-i$ "When it becomes light, they cut off the blue wool and the red wool altogether from the ritual patron. And she puts them down into the basket" (VBoT 24 obv. I 22-25); see Bawanypeck 2005, 54-55.

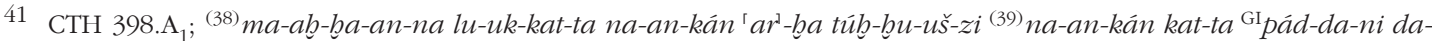
$a-i$ "When it becomes light, she cuts them (the wool) off and puts them down into the basket" (KBo 4.2 obv. I 38 ). Bawanypeck translates the sentence as "Sobald es hell wird, schneidet sie sie (die Wolle) ab und legt sie in den Korb nieder", preferring to use "sobald" instead of "wenn"; see Bawanypeck 2005, 26-27.

42 Laroche 1947, 86; Jakob-Rost 1972, 82.

43 Although Jakob-Rost proposes to translate it as "Zunge des Wachstums", the meaning of miyanit-is still unclear. For discussions see Jakob-Rost 1972, 82; CHD L-N, 235.

44 D Ariya is rarely stated in Hittite texts. Ehelolf asserted keldi as synonym of ariya; Ehelolf 1927, 143. Laroche also listed ${ }^{D} \bar{A} r a$ among the Hurrian deities, which is identified with keldi- "health"; Laroche 1947, 45. Jakob-Rost claims that the deity is treated as "the Genius of Well-Being"; Jakob-Rost 1972, 83. For attestations to this deity, see Cohen 2002, 41-44

45 Haas 1994, 473. For attestations to Šalawaneš of the Gate, see Van Gessel 1998, 367-69. 
and puts $k a r(a) \check{s}$-wheat, ${ }^{46}$ a little barley, $p a s ̌ s ̌ a-b r e a d,{ }^{47}$ a bow and three arrows in a basket, and places it under a bed, almost certainly the bed of the bewitched. She also ties ( $\mathrm{bam}(\mathrm{m}$ ) $a(n) k$-), the ašara-band, ${ }^{48}$ at the bedside and its corner posts. On the second day when it becomes light (mān lukatta), she takes the basket from under the bed, sways it over the bewitched, prays to send the sorcery back to the sorceress, cuts off (tubš-) the a ̌ara-band, and places it into the basket. ${ }^{49}$

A final example of a morning-time separation rite comes from the ritual of Tunnawiya against impurity. According to the text, a tent is built besides the river in an uncultivated place at nighttime (nekuz mebur). The Old Woman brings clay from the riverbank and wraps some ritual paraphernalia with animal fat. She also bunches together a bit of blue wool, red wool and a rope, and places them in a reed basket along with the other paraphernalia. Then she provides an ušantari-cow, ${ }^{50}$ but if it is a man, then she readies a bull. When it becomes light ( mabbhan=ma lukkitta), the ritual patron comes into the tent and puts on black clothes. Then the Old Woman takes the blue and red wool, unravels them (partai-), ${ }^{51}$ and throws them over the body of the ritual patron while speaking the charm of lifting.

Remarkably, all the ritual texts quoted above illustrate that the suitable time for a separation rite is $m \bar{a} n / m a b$ ban lukkatta/i, which refers specifically to the period of becoming light in the morning.

\section{Washing and Purification in the Morning}

As exemplified by the separation rites, the Hittites considered morning as a period for removing the impurities troubling the patient. In addition to enacting ritual transference through binding and separation, the Hittites could sometimes obtain purity by means of ritual washing and cleansing in the morning.

The first example comes from a Middle Hittite birth ritual, which belongs to a Kizzuwatnaean tradition. Purification plays an important role in this ritual, and many of its rites are performed in the morning. The text describes that when the seventh month of the pregnancy arrives, the

46 The term is translated as "Weizen, wheat" (HEG I-K, 498); Hoffner 1974, 73-74. Ertem interpreted it as "yulaf (oat)" or "çavdar (rye)"; Ertem 1974, 21-22. For an extensive discussion see Rieken 1999, 63-65. For the use of $\operatorname{kar}(a) \check{s}$ - in Hittite rituals, see Haas 2003, 382-83.

47 See CHD P, 204.

48 SíGašara-/SíGešara- is first considered as a type of wool used for tying (bamank-) or stretching (buittiya-) by Goetze and Sturtevant 1938, 85 n. 325. The term was later interpreted as "Band, Schleife" by Friedrich (HW, 35). Tischler asserted that ă̌ara-/ešara- denotes "hell" and proposed "weißes Band" for SíG ă̌ara- (HEG A-H, 79). Puhvel points out that ašara-means "white, bright" and ${ }^{\mathrm{SIG}}$ ašara- should be translated as "[strand of] white wool" (HED 1/A, 206-7).

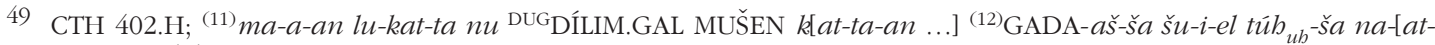
$\check{s} a-a n$... ${ }^{(13)} \check{s}$ e-er da-a-i. (KUB 41.1 rev. III 11-13); see Jakob-Rost 1972, 42-43. For an updated edition see Mouton 2013, 195-229; A. Mouton (ed.), hethiter.net/: CTH 402 (INTR 2016-03-23).

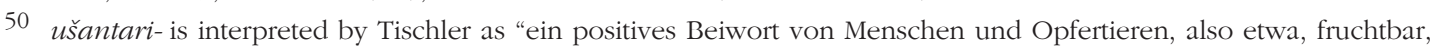
schwanger, trächtig', dann von Gottheiten, also etwa, fruchtbringend, segenspendend' und schließlich auch von Konkreta, also etwa, ertragfördernd, ertragbringend" (HEG U, 111-13). See also the translation "bringing gain, blessings" of Melchert 1993, 246.

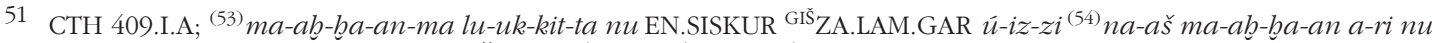
$\mathrm{GE}_{6}-T I ̇ ~ w a-a s ̌-s ̌ e-i z-z i$ nam-ma SAL.ŠU[.GI SÍG ZA.GÌN] ${ }^{55)}$ SÍG SA ${ }_{5} d a-a-i$ na-at pár-ta-a-iz-zi "When it becomes light, the ritual patron comes to the tent, and when s/he arrives, s/he wears black clothes. Then the Old Woman takes [the blue wool] (and) the red wool and disentangles it" (KUB 12.58 obv. I 53-55); see Goetze and Sturtevant 1938, 8-9; Lorenz and Taş 2012, 48; CHD P, 198; Cornil 1999, 9. 
mala-offering ${ }^{52}$ and the $u z i^{53}$ and $z u r k v^{54}$ rites are performed first, and then the purification rite is conducted. ${ }^{55}$ Following these, the next paragraph starts with the time indicator $l u k(k)$ $a t t a=m a=k a n$, illustrating that a group of rites were performed on the previous day. The following morning begins with the purification of the mouth of the pregnant woman. ${ }^{56}$ According to the text, the pregnant woman purifies her mouth ${ }^{57}$ most probably with the water in which the barnau-birthstool, ${ }^{58}$ cedar wood, olive tree and tamarisk wood are laid. ${ }^{59}$ Similarly, in the eighth month, the mouth of the pregnant woman is also washed on the (following) morning (lukkatta $=m a=k a n)$ after she washes herself on the previous day. ${ }^{60}$

Moreover, the purification ritual of Papanegri from Kizzuwatna, which is related to giving birth, is also conducted in the morning. As stated in the text, the ritual patrons return home after having sacrificed one bird for urnazḩi-61 and one bird for keldi-in the šinapši-house. There is not any ritual performance during the night, but when it becomes light (mabhan=ma lukkatta), the (newborn) baby is cleansed and a pabbišs $a^{62}$ is beaten over him/her. ${ }^{63}$ Then the offerings are brought at midday, and the ritual is terminated.

52 mala-, is thought to be borrowed from Hurrian mali, a term that symbolizes the power of manliness. See Haas and Wilhelm 1974, 67. Kümmel also discusses the relation of this term with adjective malant- "üppig, strotzend"; see Kümmel 1967, 125.

53 This is a Hurrian word for "flesh". A glossary from Ugarit allows us to trace the term in Sumerian, Akkadian, Hurrian and Ugaritic. RS 20.149 obv. II 3 ' contains [Z]U in Sumerian $=\breve{S} \bar{I} R U$ in Akkadian $=$ uzi in Hurrian $=\check{s} \hat{i} r u$ in Ugaritic. $u z i$ is frequently mentioned together with Hurrian term zurki-, which corresponds with 'ešbar' in Hittite by Laroche meaning "blood rite". Both terms are also used with the verb šipant-in numerous Kizzuwatnean rituals in the form of ' $u z i j a$ zurkija šipanti'. See Laroche 1973, 95-99; Haas 1998, 252-54; Wegner 2000, 154-55; Wegner 2007, 177; Strauß 2006, 92-98.

54 See n. 54.

55 CTH 489.A; ${ }^{(9)}[-t i \check{s} e-b y i-e l-l] i-i[n-] n a$ pa-a-i[( "She gives pur[ity ... ]" (KBo 17.65 obv. 9); see Beckman 1983, 132; Klinger 2010, 185; Mouton 2008b, 110.

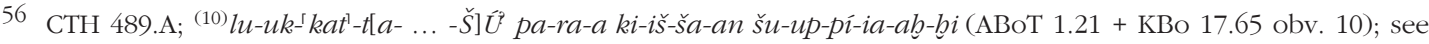
Beckman 1983, 132.

57 Purification of the mouth is a ritual practice, which is mostly evidenced in Hurrian tradition. CTH 777 contains the Hurrian rites of purification of the mouth. For detailed information see Haas 1984.

58 harnau - is translated as "birthing seat" (HW, 58 "Gebärstuhl"; HED 3/H, 174-76). But in this text it should be the figure of the birthing seat that is thrown into the beaker of the fired clay.

59 CTH 489.A; ${ }^{(10)} l u-u k-k a t-t\left[a-m a-k a ́ n{ }^{\mathrm{LU}} \mathrm{AZU}\right.$ KA×U-Š $] U p a-r a-a k i-i s ̌-s ̌ a-a n ~ s ̌ u-u p-p i-i a-a b-b i$ LÚ AZU-ša-an [( )]

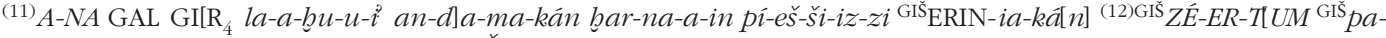
$a-i-n i$ an-d] $a$ da-a-i nu-za-kán KA $\times \mathrm{U}-\breve{S} U p a-r a-a \check{s} u-u p-p i-i a-a b-b i[(\quad)]$ "But on the following mornin[g the AZU-priest] purifies [he]r [mouth] as follows: The AZU-priest into a beaker of fired cla[y ... pours?]. But [there]in he throws barnai. And cedar(-wood), olive tree [(and) tamarisk? (-woods) there]in he places. And she purifies her own mouth." (KBo 17.65 obv. 10-12); see Beckman 1983, 132-33.

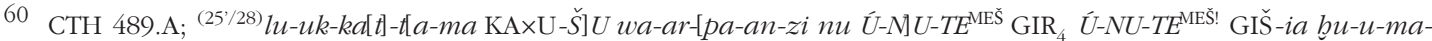
an da-a[n-n]a-ra-an-da-an da-a[š-kan-zi "[But] the following morning they wa[sh] her [mouth, and the uten]sils of fired clay and the utensils of wood - all of them empty - they ta[ke] ..." (KBo 17.65 + ABoT 1.25 rev. 25'/28); see Beckman 1983, 142; Mouton 2008b, 113.

61 See Haas and Wilhelm 1974, 101; Haas 1998, 250; Strauß 2006, 308.

62 GIšpab̧biša- is translated as "Stock(?), Gerte(?)" (HW, 153); "ein Gegenstand bzw. Schlaginstrument aus holz, mit dem Geräusche erzeugt werden” (HEG P, 361). Cf. also HED 8/PA, 3; CHD P, 9. For further information see Strauß 2006, 308-9.

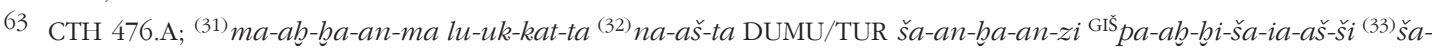
ra-a wa-al-ba-an-zi "But when it becomes light, they cleanse the baby (and) they beat a pabbiša over it" (KBo 5.1 rev. IV 31-33); see Strauß 2006, 294-303; Mouton 2008b, 95-109. 


\section{Other Rites Performed in the Morning}

A variety of other kinds of ritual practices, including the (hand-)lifting rite (UGU appatar), burial rite, the keldi-sacrifice, and the tubalzi-rite also tend to be performed in the morning.

To begin with the (hand-)lifting rite, a New Hittite Substitution Ritual clearly illustrates that both the (hand-)lifting ${ }^{64}$ and purification rites are performed in the morning. According to the text, the king makes offerings to the Moon-god at night and prays that evil omens, short years and days be taken from him, then transferred to the substitute. Then he performs the (hand-) lifting rite (UGU appatar) and washes himself. When it becomes light (GIM-an=ma lukzi), the king does the (hand-)lifting rite again, then he performs "the ritual of the house" and "the ritual of purification". Afterwards, while it is still morning the king does "the purification rite" (SISKUR balalenz $i^{65}$ ) and sacrifices one sheep to the Sun-god of Heaven. ${ }^{66}$

A burial rite, seen as a variation of the ritual transference in the rites of passage, is mentioned occurring in the morning in the ritual of Wattiti against illness. After creating an analogy with a piece of flesh by placing it into the mouth of a child, who is suffering from the shrinking of his or her entrails, on the ninth day on the following morning when the sun has not yet risen (at dawn) (lukkatta $=m a=k a n$ kuitman ${ }^{D}$ UTU-uš näwi uizzi), Wattiti rolls the flesh out and buries (bariya-) it in an offering pit while proclaiming the analogy between the flesh and the child's illness. ${ }^{67}$

The keldi-rite is among the rites that can take place at the morning period. The term is a Hurrian word translated as "wholeness, health, well-being" (HED 4/K: 142-143). Tischler interprets it as "Heil, Wohlergehen" (HEG I-K: 551). It is a kind of sacrificial rite, and shows the enduring impact of Hurrian ritual traditions, first imported in the Middle Hittite period into Hittite religion. Haas claims that the real purpose of the keldi-sacrifice is to restore the contentment of the deities that was somehow disturbed. ${ }^{68}$ Therefore, it is also possible to think of the keldi-offering as compensation. ${ }^{69}$ In the second paragraph of the birth ritual the ritual practitioner bestows purity after performing the $u z i$-rite with a bird and a lamb. Unfortunately, it is not possible to find out at which time of the day the $u z i$-rite is performed. However, the next line starts with lukkatta=ma, indicating that a new day begins. The rites are carried out on the following morning, including most probably some burning rites with birds. In the same paragraph, it is also mentioned that the practitioner makes the keldi-offering with a sheep. ${ }^{70}$

64 Bawanypeck has recently written an article on the hand-lifting rite in Mesopotamia in the second and first millennium B.C. In her study, she claims that Akkadian šu-ila "hand-lifting" rituals, which originally come from Sumerian tradition, were also performed either at night or at sunrise; see Bawanypeck 2014, 76.

65 A Luwian word balali- is translated as "clean" and balalenzi is the pl. acc. com. (HEG A-K, 126; HED 3/H, 13). For detailed information see Kümmel 1967, 33-34.

66 CTH 419.A; KUB 24.5 + KUB 9.13 obv. I 28-31. See Kümmel 1967, 10-11; Trabazo 2010, 38-39.

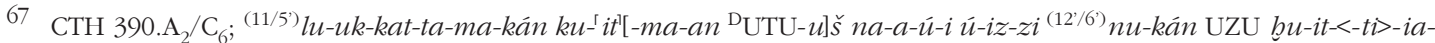
' $r i$ ' na-at bu $u$-uš-ši-li-ia ba-ri-iz-zi. (KBo $3.8+$ Bo 4010 obv. II 11'/5'-12'); see Oettinger 2004, 347-56; F. Fuscagni (ed.), hethiter.net/: CTH 390 (INTR 2017-03-06).

68 Haas 1998, 1-3 n. 3.

69 Schwemer 1995, 81-116.

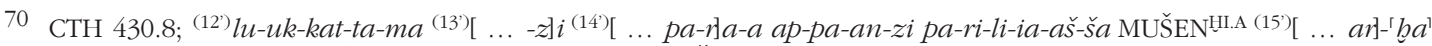

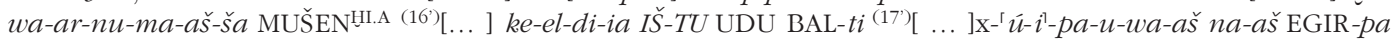
${ }^{(18)}[\ldots]$ "In the morning [ ... ] they hold forth. And the birds of pariliya $-[\ldots]$, and the birds of burning [ ... ] [ ... ] she makes a keld $i$ - offering with a sheep. [ . . ] ... Then [ . . ] they [ . . . ]" (KBo 21.45 obv. 12'-18'); see Beckman 1983, 206-9; Mouton 2008b, 132-34; F. Fuscagni (ed.), hethiter.net/: CTH 430.8 (INTR 2013-01-02). For the term parili-/parli-/paliri-, which is attested to a bird in this text, see CHD P, 154-55; Laroche 1980, 195. 
Lastly, tubalzi is a Hurrian word that is usually identified with the verb šipant-in Hittite texts. Although it was considered as an animal name or sacrifice in early studies, ${ }^{71}$ recent works tend to interpret it as a kind of offering but not necessarily an identifier of an animal sacrifice. Kronasser claimed that the tubalzi is a sacrifice but not an animal sacrifice. ${ }^{72}$ Beckman considers that the rareness of the tubalzi in Hittite rituals implies that the term denotes something concrete. It is therefore not possible to establish a more precise meaning from the few contexts. ${ }^{73}$ Tischler also interprets it as "ein Opfergegenstand und danach Benennung eines Opfers" (HEG T-D: 408). Within the scope of the ritual texts, there seems to be a connection between the tubalzi and the post-dawn, morning period. In the ritual for the expansion of the cult of the Deity of the Night, on the fifth day when it becomes light (män lukkatta), the tubalzi rite is offered with flat-bread loaves, mulati-bread, gangati-soup, cress and beer for the deity. ${ }^{74}$ The term tubalzi is also mentioned on the second day of the ritual of Papanegri. According to the text, after performing the šebelliški $i^{75}$ rite at night (nekuz mebur), the second day is spent offering two tubalzi. There is also a specific time expression "UD-az ištarna paizzi" that addresses the noon right after stating the tubalzi in this text. It is clear that the second day is spent with a tubalzi rite since the next line begins with the mention of the third day (INA UD. $\left.3^{\mathrm{KAM}}\right) .^{76}$ Although Strauß considers the tubalzi rite belonging to the nighttime, in my point of view it is more likely that this rite continued till noon on the second day, namely in the morning period since there is not any mention about nighttime in that part of the passage. However, "UD-az ištarna paizzi" signifies the daytime period. ${ }^{77}$ Another example comes from a Kizzuwatnean purification ritual. On the third and twenty-second days of this ritual, in the morning (lukkatta=ma) they perform the tubalzi rite following the šebelliški rite carried out on the previous night, which is very similar to the ritual of Papanegri. ${ }^{78}$ In the sphere of the Papanegri and Kizzuwatnean purification rituals, it should be pointed out that the tubalzi is usually offered in the morning right after the šebelliški rite, which is mostly performed during the previous night. On the other hand, only the ritual for the expansion of the cult of the Deity of the Night describes it as the keldi offering performed during the previous night in the temple of the deity before offering the tubalzi when it becomes light in the following morning.

To sum up, there are two significant points that need to be considered within the context of the typical rites. First, while ritual texts describe various types of rites associated with the morning period, the phrases designating daytime are comparatively infrequent. Thus, it is not easy

71 Sommer and Ehelolf tentatively suggested that tubalzi is a "Tierbezeichnung"; see Sommer and Ehelolf $1924,41$. Friedrich offered the translation as "ein Opfer oder Opfertier" (HW, 226).

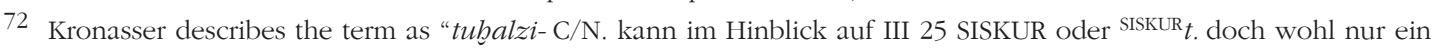
Opfer (kein Opfertier) sein, das als letztes im alten Tempel vollzogen wird”; Kronasser 1963, 52.

73 Beckman 1983, 220.

74 CTH 481.A; ${ }^{(12)} I-N A$ UD. $5^{\mathrm{KAM}} m a-a$-an $[(l u)]-u k$-kat-ta $n u$ NINDA.SIG ${ }^{\mathrm{MES}} 1{ }^{\mathrm{NINDA}} m u$ - $u$-la-ti-in ŠA $\check{S}^{1 / 2} U P-N I^{(13)} \mathrm{TU}_{7}$ ga-an-ga-t[( $i$ ZÀ.A)]H.LI 1 DUG bुa-ni-iš-ša-an KAŠ ${ }^{(14)} d a-a n-z i ~ n[u(A-N)] A$ DINGIR-LIM tu-b̧al-zi ši-pa-an-da-an-zi "On the fifth day, when it becomes light, they take 5 flat-bread loaves, 1 mulati-bread loaf of $1 / 2$ an $u p n u$-measure, gangati-herb soup, cress (and) 1 banešša-vessel of beer, and they perform the tubalzi-(ritual) for the deity" (KUB 29.4 + KBo 24.86 rev. III 12-14); see Miller 2004, 288.

75 Derived from a Hurrian rooted term šebl- "rein", this sacrifice was usually offered at night. For detailed information see Trémouille 1996a, 73-94; Strauß 2006, 98-101; Mouton 2008a, 5-6.

76 CTH 476.A; ${ }^{(56)} I-N A$ UD. $2^{\mathrm{KAM}}$-ma 2 tu-bुal-zi ši-pa-an-da-an-zi ${ }^{(57)} n a-a \check{s}$-ta a-pa-a-aš UD-az iš-tar-na pa-iz-zi. (KBo 5.1 obv. I 56-57). For the translation see Strauß 2006, 286-303; Mouton 2008b, 95-108.

77 Strauß 2006, 304 .

78 CTH 479.1; ${ }^{28)}[l u-u] k-k a t-t a-m a ~ \check{s e-b ̧ e-e l-l i-i s ̌-k i ~ E G I R-a n-d a ~ t u-b ु a l-z i-i n ~ s ̌ i-p a-a n-d a-a n-z i ~ U D ~} 4^{\mathrm{KAM}} Q A-T I$. (KBO 24.45 obv. 28); for the translation see Strauß 2006, 313-23. For the twenty-second day of the ritual, see also CTH 479.2.1; KUB 30.31 rev. IV 29-32. 
to distinguish the difference between the rites of morning and those of the daytime. It seems that the rites that begin in the morning period often continued into the daytime and terminated in the evening or at night when a new ritual cycle began. Secondly, the examples above exemplify that there are some ritual practices that are performed both in the morning and at night such as (hand-)lifting, burial and keldi rites. However, the rites of purification, whether through binding and separation or washing, as well as the tubalzi rite that seems to have habitually followed the nocturnal šebelliški rite, tend to be conducted in the morning period.

\section{Invoking the Deities in the Morning}

It is a known fact that the morning and daytime are periods closely associated with the Sungod. Engelhard argued that the rites performed during the daytime were under the jurisdiction of the Sun-god. However, the Sun-god is not the only deity invoked during the morning period since there are also chthonic deities who receive offerings during the daytime. ${ }^{79}$ On the other hand, as Mouton points out, the ritual of the Old Woman Wattiti against an illness directly correlates the night to the Sun-goddess of the Earth and the chthonic deities, while the morning to the Sun-god. ${ }^{80}$ In the ritual, Wattiti takes black, yellow, red and blue wool, intertwines them, and covers the shaft of an arrow and a spindle from box-tree wood with formerly twisted wools. She lays the objects on a thick loaf of bread, and brings them onto the roof at night (išpantaz). She puts them together with the thick loaves of bread behind the water pipe under the stars, and speaks thus: "The thousand stars will conjure it from top to the bottom, from the sky; let the heavenly gods conjure it, but on the bottom, from the dark earth let the Sun-goddess of the Earth conjure it' ${ }^{81}$ Then she leaves the paraphernalia under the stars. On the following morning when the sun rises (lukkatta $=m a=k a n{ }^{D} \mathrm{UTU}-u \check{s} u p z i$ ), she takes them from the roof, breaks the haršaima-bread for the Sun-god, and speaks: "During the night the thousand stars and the deities put a spell on it; also the Sun-goddess of the Earth has conjured it. Now, you, the Sun-god, should conjure it". ${ }^{82}$

With regard to the concepts of morning and their relationship with the offerings to the deities in Hittite rituals, a distinction can be made between dawn, on the one hand, and sunrise, on the other, in terms of the favorable time to make offerings to the heavenly and chthonic deities. It can be seen in the texts that karuwariwar, identified with the dawn in the first part of this study, is the time when the chthonic deities, particularly the Sun-goddess of the Earth, are generally meant to be invoked. ${ }^{83}$

Keeping with the rituals discussed above, most of the examples of contacting the chthonic deities are found in the purification rituals, and dawn is specified as a favorable time to invoke them. The first example comes from the purification ritual of a house. It is understood from the text that the ritual starts at dawn (karuwariwar) by opening the house. ${ }^{84}$ After entering

79 Engelhard 1970, 210-14.

80 Mouton 2008a, 8.

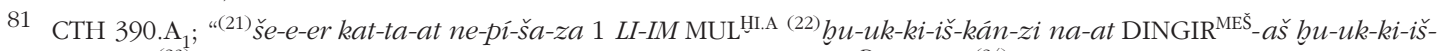
$k i-i d-d u{ }^{(23)} k a t-t e-r a-m a-a t d a-a n-k u-w a-a z$ ták-na-a-az ták-na-aš ${ }^{\mathrm{D} U T U-u s ̌ ~}{ }^{(24)} b u-u k-k i-i s ̌-k i-i d-d u$ " (KUB 7.1 obv. II 21-24); see Kronasser 1961, 148-51; F. Fuscagni (ed.), hethiter.net/: CTH 390 (INTR 2017-03-06).

82 CTH 390.A ${ }_{1}$ " "(27) iš-pa-an-ti-wa-ra-at 1 LI-IM MUL ${ }^{\mathrm{HI} . \mathrm{A}}{ }^{(28)}{ }^{\mathrm{DINGIR}}{ }^{\mathrm{MES}}$-aš-ša bुu-uk-ki-iš-ki-ir ták-na-aš-ša-wa-ra-at ${ }^{(29) \mathrm{D} U T U-u s ̌ ~ h u-u k-k i-i \check{s}-k i-i t}{ }^{\left({ }^{30}\right)} k i-n u-n a-w a-r a-a t z i-i k{ }^{\mathrm{D} U T U}-u s ̌ ~ h u-u k-k i-i \check{s}-k i$ " (KUB 7.1 obv. II 27-30); see Torri 2003, 76; F. Fuscagni (ed.), hethiter.net/: CTH 390 (INTR 2017-03-06).

83 Janowski 1989, 98-105.

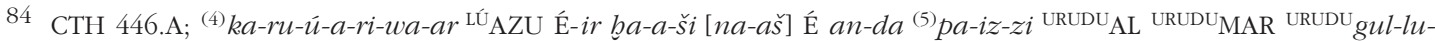
bi bar-zi "At dawn the AZU-priest opens the house [and he] goes into it. He holds a hoe, a spade and a bucket." 
into it and digging the ground with the hoe and clearing the pit with a spade, the ritual practitioner digs in the same way in the four corners of the house and to the side of the hearth. He speaks to the Sun-goddess of the Earth in order to find out the reason for the evil affecting the house. ${ }^{85}$ Then the rites are performed to purify the house from evil (HUL-lu), impurity (papratar), perjury (Nİ̌ DINGIR ${ }^{L I M}$ ), bloodshed (ēšbar), curse (burtai-), threat (kurkurai-), tears (ēšbabru), and sin (waštai-). Moreover, in the ritual of Ammihatna against impurity, the AZU-priest takes some of the ritual paraphernalia on the first day when the sun has not taken its place yet (kuitman ${ }^{\mathrm{D} U T U}-u \check{S} A \breve{S} A R=\check{S} U$ nāwi ēpzi) ${ }^{86}$ and goes to the riverbank. After making offerings and libations there, he demands water from the Sun-goddess of the Earth.

The period of becoming light also plays an important role in the funerary ritual. The ritual practitioners make offerings to the deities, which mostly have a chthonic nature. On the third, seventh, tenth, and twelfth days of that ritual, some parts of the rites are performed when it becomes light (mān lukkatta). With the exception of the third day, the practices carried out at that period of the day are quite similar. ${ }^{87}$ The participants begin to perform the rites when it becomes light. These consist of treating the statue of the deceased and making offerings to the Sun-goddess of the Earth, to the Sun-goddess of Heaven, to the grandfathers and grandmothers ( (DUD.SIG $)_{5}$ ". This happens while the statue of the deceased is still in the house. The funerary ritual is a text suigeneris, and it is difficult to compare it with other magical rituals. However, it is clear that the invocation of both chthonic and heavenly deities takes place when it becomes light in the morning since the term män lukkatta may include both dawn and sunrise.

Furthermore, there are also specific deities that are invoked in the morning in Hittite rituals. For instance, in the ritual of Paškuwatti against effeminacy, after performing the rites in an uncultivated place in the steppe, Paškuwatti and the ritual participants go to the house of the patient, where a bed is placed in front of the offering table of the goddess Uliliyaši . While the patient is lying down, either the KUSİTU-garments ${ }^{88}$ or the cloak $^{89}$ are spread out each night for three days. But on the first day, the practitioner entreats Uliliyaši three times by breaking thick loaves of bread at dawn, at midday, and at dusk while scattering groats. ${ }^{90}$ It is clear that here karuwariwar "dawn" is one of the three periods of the day during which the goddess Uliliyaš $i$ is evoked (mugai-) $)^{91}$ through a sacrifice of a sheep.

(KUB 7.41 obv. I 4-5); see Otten 1961, 114-57; Miller 2008, 206-17. The text was also edited by Andrea Trameri in his MA thesis, which he is currently revising for publication.

85

CTH 446.A; KUB 7.41 obv. I 9-22.

86

87

CTH 471.A; KBo 5.2 obv. I 42. See Strauß 2006, 216-52; Mouton 2016, 282-319.

On the third day of the funerary ritual after the burning ceremony, the women go to the pyre when it becomes light and gather the bones. CTH 450.I.3; (1)" ma-a-an I-NA UD. $3^{\text {!KAM }} l u$-uk-kat-ta nu MUNUS ${ }^{\mathrm{MES}} u k$-tul-u-ri-j] $a^{\text {? }}$ ha$a \check{s}$-ti-ă̌ li-eš-šu-wa-an-zi" (KUB 30.15 (528/f) obv. 1); see Kassian et al. 2002, 260-61; Groddek 2001, 111-12 (no. 103); Mouton 2016, 126-27.

88 KUSİTU is equated with Sumerian TÚG.BAR.DUL, , which is explained as "an elaborate garment" in CAD K, 585. Košak translates it as "long gown garment"; see Košak 1982, 248.

89 Both Goetze and Košak translate TÚG.GÚ.É.A as "shirt" by equating it with the Akkadian NAHLAPTU; see Goetze 1969, 350; Košak 1982, 278.

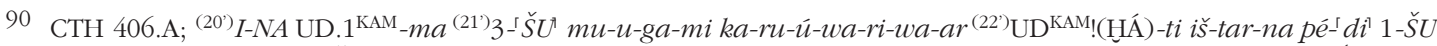
$n e-k u-u z$ me-bुur ${ }^{\left(23^{\prime}\right)} 1-\check{S} U$ me-mi-ia-nu-ša-kán an-da a-pu-u-uš-pát ${ }^{\left(24^{\prime}\right)} m e-m i-i \check{s}-k e-m i$ NINDA.GUR ${ }_{4} \cdot \mathrm{RA}^{\mathrm{HA}}-i a^{\left(25^{\prime}\right)}$ $k u-i-u \check{s} k a-r u-\bar{u}-w a-r i-w a-a r^{\left(26^{\prime}\right)} p a ́ r-s ̌ i-i a-a n-n a-a b-b i$ "But on the first day, I evoke (the deity) three times at dawn (once), at midday once and at dusk once. In doing so, I speak those very words. And at dawn I break some thick loaves of breads." (KUB 7.5 obv. II 20'-26'); see Hoffner 1987, 278; Trabazo 2002, 460-61; Mouton 2016, 230-51. 
In a summary tablet of the funerary ritual, ${ }^{92}$ the ritual practitioner offers one sheep to the deities in the morning (lukkatti=ma). But besides the Sun-god and the gods of Heaven, the Sun-goddess of the Earth, the netherworld goddess Allani, ${ }^{33}$ and the deities of the Earth also receive a sheep offering in the morning. ${ }^{94}$

In a ritual of the Tutelary Deity of the Hunting Bag 'DLAMMA KUŠ kuršaš, after completing the rites on the second day, on the third day in the morning at dawn (lukkatta=ma INA UD. $3^{\text {KAM }}$ karuwariwar), ${ }^{95}$ the Old Woman goes in front of the statue of DLAMMA Kuš ${ }^{\text {kuršaš, }}$, ${ }^{96}$ where she waves the freshly roasted grain over the deity and the augurs. Then she prays to send the evil and terrifying words away, and pours out the grain to the bekur-. ${ }^{77}$ From this point on, the ritual practices are performed at night. But on the fifth day of the same ritual, on the (following) morning (lukkatta=ma) the augurs come to take the deity (i.e. the statue) from the temple. This indicates that they carry out the rites on the fourth day inside the temple. ${ }^{98}$ However, on the fifth day in the morning $(l u k k a t t a=m a)$ the ritual practitioner does not go into the temple, and the ritual patron has to give him the ritual paraphernalia to be offered to the Sun-god. ${ }^{99}$ With regard to the text, it is significant that the offerings for the Sun-god are made in an outdoor place. Bawanypeck also asserts that the offering rite performed by the ritual practitioner should have taken place at sunrise (Sonnenaufgang) in the outdoors. ${ }^{100}$

Finally, the offerings to different deities in the morning are described in the ritual of Kuwanni, a priestess from Kizzuwatna and woman of the temple of Kummanni. On the first day in the morning (lukkatta) an offering table for Hepat, Zulkappi ${ }^{101}$ and Temu ${ }^{102}$ is

disaffected soul of the deceased. For detailed information see also Singer 2002. In his recent study on mugai-, Melchert argues that mugai- denotes "to rouse, bestir, urge to action" by referring to the study of Laroche; see Melchert 2010, 207-15; Laroche 1964, 20-24.

92 See the edition of S. Görke (ed.), hethiter.net/: CTH 451 (INTR 2015-06-08). Kapełus considers that CTH 451 is a text about the case of king's death in another city and the descriptions represent transporting the body from another country; see Kapełús 2011, 145.

93 Allani is identified with the Sun-goddess of the Earth in Hittite Anatolia. However, the deity literally is Hurrian in origin and worshiped as "Lady of the Underworld" under the name of Akkadian Allatum and Sumerian EREŠ. KI.GAL. The Hittites also used Allatum as an Akkadogram for Lelwani during the Empire Period. In the epic of liberation (CTH 789; KBo 32.11 obv. I 1-6) Allani is defined as "a young lady who stays at the bolt of the Earth"; see Neu 1996, 30. For detailed information see Haas 1994, 130-33; Popko 1995, 99; Janowski 1989, 98-99; Karasu 2003, 231; Archi 2002, 22.

94 CTH 451; KUB 30.27 rev. 4-8; see Otten 1958, 98-99; S. Görke (ed.), hethiter.net/: CTH 451 (INTR 2015-06-08).

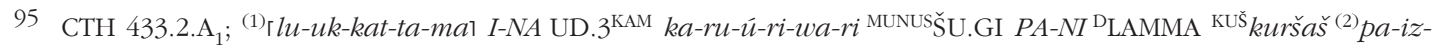
$z i$. (KBo 17.105 rev. III 1-2; see Bawanypeck 2005, 90-1; McMahon 1995, 263-74).

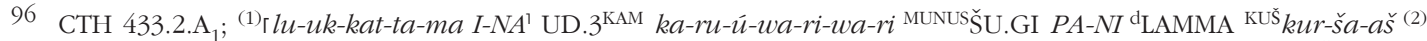
$p a-i z-z i$ "But in the morning on the third day at dawn the Old Woman goes in front of the DLAMMA KUŠ $k u r s ̌ a s "$. (KBo 17.105 rev. III 1-2); see Bawanypeck 2005, 84-105; McMahon 1995, 263-74.

97 NA4bekur-is traditionally translated as "rock-sanctuary, hierothesion, acropolis" (HED 3/H, 287). But here, as Bawanypeck mentioned, it is the plural form of "der Fels (Felsen)"; see Bawanypeck 2005, 100. For a detailed examination see Rieken 1999, 287-89; Van den Hout 2002, 75; Harmanşah 2015, 43-45; Groddek 2002c, 213-18.

98 CTH 433.1.A; ${ }^{(20)} l u-u k$-kat-ta-ma A-NA DINGIR ${ }^{L I M} k a r-p u-u$-wa-an-zi ú-wa-an-zi "But on the (following) morning they come to take the deity away" (KBo 12.96 rev. IV 20); see Bawanypeck 2005, 76-77.

99 CTH 433.1; ${ }^{(21)}$ am-mu-uk-kán a-pé-e-da-ni I-NA UD. $5^{\mathrm{KAM}(22)}$ I-NA ŠÀ É.DINGIR ${ }^{L I M}$ Ú-UL pa-a-i-mi. (KBo 12.96 rev. IV 21-22); see Bawanypeck 2005, 76-77.

100 Bawanypeck 2005, 216.

101 This is a Hurrian deity associated with goddess Hepat. For the texts in which Zulkappi is stated, see Laroche 1980, 307; Van Gessel 1998, 602.

102 For the texts in which Tenu/Temu is mentioned, see Laroche 1980, 262; Van Gessel 1998, 480-81. Haas pointed out that he is the vizier (LÚSUKKAL) of Tešub, and a monthly festival is celebrated in Halab for the deity Tenu/ Temu; see Haas 1994, 332. Trémouille also claims that the name Tenu/Temu is always stated at the end of the list of male deities; see Trémouille 1996b, 98. 
prepared. ${ }^{103}$ As stated in the text, the rites of the first day possibly last till the evening, as Kuwanni places the ritual paraphernalia at the bedside, and the ritual patron sleeps there the whole night.

\section{The Fleeting Nature of the Ritual Practices in the Morning}

As mentioned in the first part of this article, a fair number of ritual texts emphasize the fleeting nature of the ritual performances during the morning period with the word pattern mann lukkatta ... karuwariwar. And an adverb budak identifies the verb in order to specify the promptness of the action. The actions taken during the fleeting morning ritual period are mostly designated by the verbs pai- "to go", penna- "to drive (away)", unna- "to drive (towards)", and uwa- "to come". These indicate a change in the ritual space, which most probably necessitated acting in a quick manner.

The first example comes from the ritual of Ašhella against an epidemic in the army. It is seen that the swiftness of ritual performances during män lukkatta ... karuwariwar is emphasized on the second, third, and fourth days during which the offerings are taken up promptly when it becomes light at dawn. They are brought to the steppe to perform the rites for the deity that has sent the epidemic into the army. It should also be noted that on the morning of the first day (luk(k)atti), the "scapegoat" rite is performed by carrying the rams, the adorned woman, one thick loaf of bread, and beer through the middle of the army, driving them outside in the steppe, and leaving them on the borders of the enemies. Likewise, on the second, third, and fourth days of the ritual, the sacrificial ceremony is performed in an immediate manner when it becomes light at dawn (män lukkatta ... karuwariwar). According to the text, the ritual paraphernalia is prepared, and then taken to the place where the ceremony is held. ${ }^{104}$

Additionally, in a Kizzuwatnean ritual to expand the cult of the Deity of the Night on the third day when it becomes light at dawn (män lukkatta ... karuwariwar), the ritual patron comes promptly into the temple. ${ }^{105}$ It is noteworthy here that there is an additional sentence mentioning "when the stars still stand". This possibly signifies early dawn, which was discussed in the first part of this study.

Finally, there are also some ritual fragments including this pattern. In the taknaz dāritual, ${ }^{106}$ at dawn on the morning of the second day, they promptly do some action that is not

103 CTH 474.1.A;; ${ }^{(8)} l u-u k-k a t-t[a \ldots]{ }^{(9)} t i-i a-a n-z[i]$ "In the mornin[g ...] they plac[e]". (FHG 13a obv. I 8'); see Groddek 1996, 300-1; Groddek 2004, 44-45, 57-58; S. Görke (ed.), hethiter.net/: CTH 474.1 (INTR 2015-08-14).

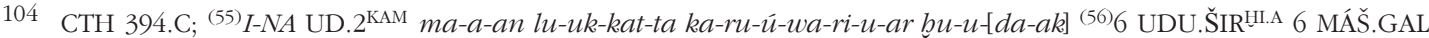

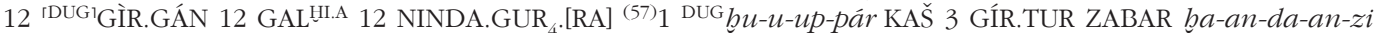
"On the second day when it becomes light at dawn, they prepare prom[ptly] 6 rams, 6 male-goats, 12 GìR.KÁNvessels, 12 cups, 12 thick loaves of brea[d], 1 buppar-vessel (and) 3 small knives from bronze". (13) $I-N A$ UD. $3^{\text {KAM }}$

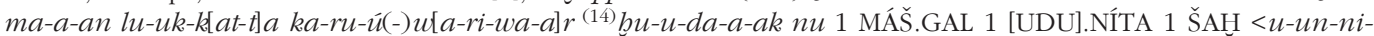
$a n-z i>$ "On the third day, when it g[ets ligh]t at d[awn], they drive promptly a male-goat, one [ram] (and) a pig."

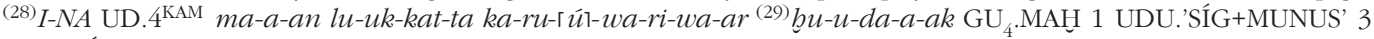
UDU.NIITA $u$-un-ni-ia-an-zi "On the fourth day, when it becomes light at d[a]wn, they drive promptly a bull, an ewe, 3 rams, (and maybe) an ewe to which a ram has not yet gone." (KUB 9.31 rev. III 55-57; rev. IV 13; rev. IV 28); see Dinçol 1985, 1-40; Mouton 2016, 169-89; A. Chrzanowska (ed.), hethiter.net/: CTH 394 (INTR 2016-07-13).

105 CTH 481; ${ }^{14)}$ I-NA UD. $3^{\mathrm{KAM}}-m a$ ma-a-an lu-uk-kat-ta nu EN.SÍSKUR ka-ru-ú-a-ri-wa-ar ${ }^{(15)} b u$-u-da-ak I-NA É.DINGIR-LIM $\tilde{u}^{-}-i z-z i$ MUL ${ }^{\text {HI.A }} n u-u-a$ a-ra-an-da "But on the third day when it becomes light and the ritual patron comes promptly into the temple at dawn, (when) the stars still stand" (KUB 29.4 obv. II 14-15); see Miller 2004, 281.

106 It is literally interpreted as "to take from/out of the Earth", which is basically a kind of substitution ritual. For a comprehensive commentary on taknaz $d \bar{a}$-rituals, see Taracha 2000, 213-24, especially n. 2 on p. 213. For a further bibliography, see Görke 2010, 174-79. 
possible to understand due to a gap in the tablet. Then the participants take the precious garments from the storehouse (ÉSAG) and bow to the Sun-god. ${ }^{107}$ Additionally, in a fragment of a mugawar, when the HAL-priest evokes the Storm-god and summons him to the uninhabited place outside the city, on the first day in the morning at dawn, he goes promptly to the nine fireplaces, and sets nine tables at each place on which the offerings for the deity stand. ${ }^{108}$

\section{Conclusions}

This study was designed to determine the concepts of morning and the perception of time in Hittite magical rituals. Although there is not a predetermined calendrical date for the magical rituals, the texts clearly show that Hittite rituals have their own sense of time. This study reinforces the idea that time had a profound effect on these religious performances and that Hittites were concerned about the time of the rites with due consideration.

There are various patterns used to express the different phases of the morning in Hittite rituals. This supports the idea that the morning is one of the most frequently attested time periods. It is possible to analyze them in two groups. The first includes the terms luk(k)atta, which means morning in general and karuwariwar, denoting dawn. The second comprises the word patterns formed by referring to the location and motion of the sun. It should be noted that the latter designates a more specific point of time at morning by describing the position of the sun in the sky. Consistent with the rituals, I observed that the perception of time is strictly bound up with the ritual action and the mention of time usually refers to the beginning of a new group of rites. This study has shown that the rites such as the separation, purification, the (hand-)lifting, keldi and the tubalzi are performed in the morning. This is expressed by the phrases such as mān/mab̧ban lukkatta/i, and GIM-an lukzi, which correspond to the period of becoming light in the morning and probably comprise the sunrise. On the other hand, the burial rite is performed on the (following) morning when the sun has not risen yet (lukkatta=ma=kan kuitman ${ }^{\mathrm{D} U T U}-u s ̌$ näwi uizzi), which means dawn, that is, the period before the sun becomes visible on the horizon.

This article also contributes to the field by putting forward three significant results related with the morning period.

1. The tubalzi rite was usually performed in the morning after the nocturnal šebelliški rite.

2. The Hittites differentiated between dawn and the sunrise regarding the invocation of the deities. Although morning was generally related to the Sun-god, the texts suggest that the dawn (karuwariwar) held a special place as the last moment to contact the chthonic deities, especially the Sun-goddess of the Earth.

3. The fleeting nature of the ritual practices in the morning is mostly expressed by the use of the adverb budak. This study reveals that it is most probably due to the change of the ritual place identified with the verbs "to go, to drive (away, towards), and to come", which

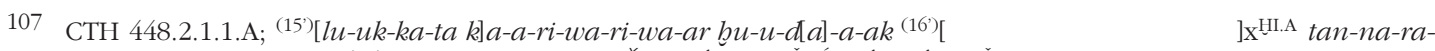

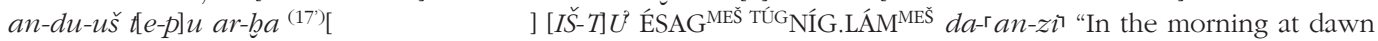
pro[mpt]ly [ ] empty a [litt]le bit away [ ] they take the precious garments [fro]m the storehouses" (KUB 17.18 obv. I 15'-17'); see S. Görke (ed.), hethiter.net/: CTH 448.2.1.1 (INTR 2016-07-01).

108 CTH 459.1; (5) $l u(k) k a t t i=m a$ INA UD.1 ${ }^{\text {KAM }}$ karüwari[war] buüdak paizzi. "But in the morning on the first day at da[wn], he goes promptly" (KBo 48.110 + KUB 9.9 + KBo 13.130 + KBo 49.153 obv. I 5); see Groddek 2012, 77 ; Kümmel 1967, 41; Groddek 2013, 94. 
necessitates acting in a quick manner. It also refers to the fleeting nature of the time between the late dawn and sunrise.

This article has assessed the terminology and typical rites of the morning period. Despite the promising results discussed above (see also fig. 1), there is still a lack of studies in the field that focus on the morning period as well as on the other parts of a day. To develop a fuller picture of the perception of time in Hittite rituals, further investigations need to be undertaken.

FIG. 1 Significant results related with the morning period in Hittite magical rituals.

\begin{tabular}{|c|c|c|c|}
\hline & \multicolumn{2}{|c|}{ Terms/Phrases } & Rites \\
\hline \multirow[t]{2}{*}{ Morning } & $\operatorname{luk}(k) a t t a / i$ & morning & $\begin{array}{l}\text { Ritual washing and purification, } \\
\text { keldi-sacrifice, tubalzi-rite, } \\
\text { offerings to the deities. }\end{array}$ \\
\hline & $\begin{array}{l}\text { mān/mab̧ban luk(k)atta/GIM- } \\
\text { an lukzi }\end{array}$ & when it becomes light & $\begin{array}{l}\text { Rites of separation, } \\
\text { purification rite (SISKUR } \\
\text { balalenzi), (hand-)lifting rite, } \\
\text { and tubalzi-rite, invocation } \\
\text { mostly of the chthonic deities. }\end{array}$ \\
\hline \multirow[t]{2}{*}{ Early Dawn } & $\begin{array}{l}\text { mān lukkatta ... karuwariwar... } \\
\text { MUL }{ }^{\text {HI.A }} \text { nuwa aranda }\end{array}$ & $\begin{array}{l}\text { when it becomes light ... at } \\
\text { dawn ... when the stars still } \\
\text { stand }\end{array}$ & \multirow[t]{2}{*}{$\begin{array}{l}\text { Emphasis on the promptness of } \\
\text { the ritual actions (budak). }\end{array}$} \\
\hline & $\begin{array}{l}\text { mahbुan=ma } \mathrm{GE}_{6}-\text { anza lukzi } \\
\text { MULUD.ZAL.LE=kan uizzi lukzi } \\
\text { nāwi }\end{array}$ & $\begin{array}{l}\text { but when the night grows } \\
\text { brighter and the morning star } \\
\text { rises, (while) it has not yet } \\
\text { become light }\end{array}$ & \\
\hline \multirow[t]{5}{*}{ Dawn } & karuwariwar & dawn & $\begin{array}{l}\text { Invocation of the chthonic } \\
\text { deities viz. the Sun-goddess of } \\
\text { the Earth. } \\
\text { Emphasis on the promptness of } \\
\text { the ritual actions (budak). }\end{array}$ \\
\hline & mān lukkatta ... karuwariwar & $\begin{array}{l}\text { when it becomes light ... at } \\
\text { dawn }\end{array}$ & $\begin{array}{l}\text { Emphasis on the promptness of } \\
\text { the ritual actions (budak). }\end{array}$ \\
\hline & $\begin{array}{l}\text { lukkatta= ma=kan kuitman } \\
\text { DUTU-uš nāwi uizzi }\end{array}$ & $\begin{array}{l}\text { but on the (following) morning } \\
\text { when the sun has not risen yet }\end{array}$ & Burial rite. \\
\hline & $\begin{array}{l}\text { kuitman }{ }^{\mathrm{D} U T U}-u \check{S} A \check{S} A R=\check{S} U \\
\text { nāwi ēpzi }\end{array}$ & $\begin{array}{l}\text { when the sun has not taken its } \\
\text { place yet }\end{array}$ & $\begin{array}{l}\text { Invocation of the Sun-goddess } \\
\text { of the Earth. }\end{array}$ \\
\hline & $\begin{array}{l}\text { lukkatta=ma INA UD.x.KAM } \\
\text { karuwariwar }\end{array}$ & $\begin{array}{l}\text { but in the morning on the Xth } \\
\text { day at dawn }\end{array}$ & $\begin{array}{l}\text { Invocation of the DLAMMA } \\
\text { KUŠ kuršaš }\end{array}$ \\
\hline Sunrise & lukkatta $=m a=k a n^{\mathrm{D}} \mathrm{UTU}-u s ̌$ upzi & $\begin{array}{l}\text { but on the (following) morning } \\
\text { (when) the sun rises }\end{array}$ & Invocation of the Sun-god. \\
\hline
\end{tabular}




\section{Bibliography}

Archi, A. 2002. "Formation of the West Hurrian Pantheon: The Case of Išhara." In Recent Developments in Hittite Archaeology and History Papers in Memory of Hans G. Güterbock, edited by K.A. Yener and H.A. Hoffner Jr., 21-33. Winona Lake, IN: Eisenbrauns.

Bawanypeck, D. 2005. Die Rituale der Auguren. Texte der Hethiter 25. Heidelberg: Carl Winter.

Bawanypeck, D. 2014. "Normative Structures in Mesopotamian Rituals: A Comparison of Hand-lifting Rituals in the Second and First Millennium B.C." In Traditions of Written Knowledge in Ancient Egypt and Mesopotamia, edited by D. Bawanypeck and A. Imhausen, 71-89. AOAT 403. Münster: Ugarit.

Beckman, G. 1983. Hittite Birth Rituals. Studien zu den Boğazköy-Texten 29. Wiesbaden: Harrassowitz.

Beckman, G. 1989. "The Religion of the Hittites." Biblical Archaeologist 52.2-3:98-108.

Beckman, G. 2017. "Zeit (time). B. Bei den Hethitern." RLA 15:248-50.

Carruba, O. 1980. Review of The Hittite Dictionary of the Oriental Institute of the University of Chicago. Vol. 3, Fasc. 1, by H.G. Güterbock and H.A. Hoffner. SMEA 22:363-64.

Cohen, Y. 2002. Taboos and Probibitions in Hittite Society. Texte der Hethiter 24. Heidelberg: Carl Winter.

Collins, B.J. 1990. "The Puppy in Hittite Ritual.” JCS 42.2:211-26.

Cornil, P. 1999. "La tradition écrite des textes magiques hittites." Ktema 24:7-16.

Daddi, F.P., and A.M. Polvani. 1990. La mitologia ittita. Brescia: Paideia.

Dinçol, A.M. 1985. "Ašḩella Rituali (CTH 394) ve Hititlerde Salgın Hastalıklara Karşı Yapılan Majik İşlemlere Toplu Bir Bakış.” Belleten 49.193:1-40.

Ehelolf, H. 1927. "Zum hethitischen Lexikon." KF 1.1:137-60.

Engelhard, D.H. 1970. "Hittite Magical Practices: An Analysis." Ph.D. diss., Brandeis University.

Ertem, H. 1974. Boğazköy Metinlerine Göre Hititler Devri Anadolu'sunun Florası. Ankara: Türk Tarih Kurumu.

Goetze, A., and E.H. Sturtevant. 1938. The Hittite Ritual of Tunnawi. American Oriental Society 14. New Haven, CT: American Oriental Society.

Goetze, A. 1969. "Hittite Rituals, Incantations, and Description of Festival." In Ancient Near Eastern Texts Relating to the Old Testament, edited by J.B. Pritchard, 346-61. Princeton Studies on the Near East. Princeton, NJ: Princeton University Press.

Görke, S. 2010. Das Ritual der Aštu (CTH 490) - Rekonstruktion und Tradition eines hurritisch-hethitischen Rituals aus Boğazköy / Hattuša. Culture and History of the Ancient Near East 40. LeidenBoston: Brill.

Groddek, D. 1996. "Fragmenta Hethitica dispersa IV." Altorientalische Forschungen 23.2:298-307.

Groddek, D. 2001. "Fragmenta Hethitica dispersa XI." Altorientalische Forschungen 28:108-19.

Groddek, D. 2002a. Hethitische Texte in Transkription: KUB 55. Dresdner Beiträge Hethitologie 4. Dresden: Verlag der TU.

Groddek, D. 2002b. "Die rituelle Behandlung des verschwundenen Sonnengottes (CTH 323)." In Silva Anatolica: Anatolian Studies Presented to Maciej Popko on the Occassion of His 65th Birthday, edited by P. Taracha, 119-31. Warsaw: Agade.

Groddek, D. 2002c. "Mausoleum (É.NA $)$ und Totentempel (É bištāa) im Hethitischen." UgaritF 33:213-18.

Groddek, D. 2004. Hethitische Texte in Transkription: KBo 39. Dresdner Beiträge Hethitologie 11. Dresden: Verlag der TU.

Groddek, D. 2012. Hethitische Texte in Transkription: KBo 48. Dresdner Beiträge Hethitologie 38. Wiesbaden: Harrassowitz. 
Groddek, D. 2013. Hethitische Texte in Transkription: KBo 49. Dresdner Beiträge Hethitologie 40. Wiesbaden: Harrassowitz.

Güterbock, H.G. 1997. "Some Aspects of Hittite Festivals." In Perspectives in Hittite Civilization: Selected Writings of Hans Gustav Güterbock, edited by H.A. Hoffner Jr. and I.L. Diamond, 87-90. AS 26. Chicago: The Oriental Institute.

Haas, V., and G. Wilhelm. 1974. Hurritische und luwische Riten aus Kizzuwatna. AOAT Sonderreihe 3. Neukirchen-Vluyn: Neukirchener.

Haas, V. 1984. Die Serien itkab̧i und itkalzi des AZU-Priesters. Rituale für Tašmišarri und Tatubepa sowie weitere Texte mit Bezug auf Tašmišarri. Corpus der hurritischen Sprachdenkmäler 1.1. Rome: Multigrafica.

Haas, V. 1988. "Magie und Zauberei. B. Bei den Hethitern.” RLA 7:234-55.

Haas, V. 1994. Geschichte der hethitischen Religion. Handbuch der Orientalistik 1. Der Nahe und der Mittlere Osten 15. Leiden: Brill.

Haas, V. 1998. Die hurritischen Ritualtermini in bethitischem Kontext. Corpus der hurritischen Sprachdenkmäler 1.9. Rome: Bonsignori.

Haas, V. 2003. Materia Magica et Medica Hethitica: Ein Beitrag zur Heilkunde im Alten Orient. Vol. 1. Berlin/New York: De Gruyter.

Haas, V. 2006. Die hethitische Literatur: Texts, Stilistik, Motive. Berlin/New York: De Gruyter.

Harmanşah, Ö. 2015. Place, Memory and Healing: An Archaeology of Anatolian Rock Monuments. London/New York: Routledge.

Hoffner, H.A. 1974. Alimenta Hethaeorum Food Production in Hittite Asia Minor. American Oriental Series 55. New Haven, CT: American Oriental Society.

Hoffner, H.A. 1987. "Paskuwatti's Ritual Against Sexual Impotence (CTH 406).” Aula Orientalis 5:271-87.

Hoffner, H.A. 1998. Hittite Myths, edited by G.M. Beckman. 2nd ed. Society of Biblical Literature, Writings from the Ancient World. Atlanta: Society of Biblical Literature.

Jakob-Rost, L. 1972. Das Ritual der Malli aus Arzawa gegen Behexung. Texte der Hethiter 2. Heidelberg: Carl Winter.

Janowski, B. 1989. Rettungsgewißheit und Epiphanie des Heils: Das Motiv der Hilfe Gottes „am Morgen“ im Alten Orient und im Alten Testament. Wissenschaftliche Monographien zum Alten und Neuen Testament 59. Neukirchen-Vluyn: Neukirchener.

Joseph, B. 1988. "On the Etymology of Hittite tuqqāri 'be visible'." In A Linguistic Happening in Memory of Ben Schwartz: Studies in Anatolian Italic, and other Indo-European Languages, edited by Y.L. Arbeitman, 205-13. Bibliothèque des Cahiers de l'Institut de linguistique de Louvain 42. Louvain-la-Neuve: Peeters.

Kammenhuber, A. 1961. Hippologia Hethitica. Wiesbaden: Harrassowitz.

Kapełuś, M. 2011. "On Different Texts of the Hittite Royal Funerary Rituals (CTH 450 reconsidered).” In Hethitische Literatur: Überlieferungsprozesse, Textstrukturen, Ausdrucksformen und Nachwirken, Akten des Symposiums vom 18. bis 20. Februar 2010 in Bonn, edited by M. Hutter and S. HutterBraunsar, 145-56. AOAT 391. Münster: Ugarit.

Karasu, C. 2003. "Why did Hittites Have Thousands of Deities?" In Hittite Studies in Honor of Harry Hoffner Jr. on the Occasion of His 65th Birthday, edited by G. Beckman, R. Beal, and G. McMahon, 221-36. Winona Lake, IN: Eisenbrauns.

Kassian, A., A. Korolëv, and A. Sidel'tsev. 2002. Hittite Funerary Ritual šalliš uaštaiš. AOAT 288. Münster: Ugarit.

Klinger, J. 2010. "Hethitische Texte zur Medizin.” In Texte Zur Heilkunde, edited by B. Janowski and D. Schwemer, 177-88. Texte aus der Umwelt des Alten Testament, Neue Folge 5. Gütersloh: Gütersloher Verlagshaus. 
Kloekhorst, A. 2008. Etymological Dictionary of the Hittite Inherited Lexicon. Leiden Indo-European Etymological Dictionary Series 5. Leiden/Boston: Brill.

Košak, S. 1982. Hittite Inventory Texts (CTH 241-250). Texte der Hethiter 10. Heidelberg: Carl Winter.

Kronasser, H. 1961. "Fünf hethitische Rituale." Die Sprache 7:148-51.

Kronasser, H. 1963. Die Umsiedelung der Schwarzen Gottheit: Das hethitische Ritual KUB XXIX 4 (des Ulippi). Sitzungsberichte - Österreichische Akademie der Wissenschaften. PhilosophischHistorische Klasse 241.3. Vienna: Böhlau.

Kümmel, H.M. 1967. Ersatzrituale für den hethitischen König. Studien zu den Boğazköy-Texten 3. Wiesbaden: Harrassowitz.

Laroche, E. 1947. "Recherches sur les noms des dieux hittites." RHA 7.46:7-139.

Laroche, E. 1964. "La prière hittite: vocabulaire et typologie." École pratique des Hautes Études 72:20-24.

Laroche, E. 1973. "Études de Linguistique Anatolienne.” RHA 31:95-99.

Laroche, E. 1980. Glossaire de la langue hourrite. Études et commentaires 93. Paris: Editions Klincksieck.

Lebrun, R. 1979. "Le Rituel d'Ammihatna, Tulbi et Mati contre une impureté.” Hethitica 3:139-64.

Lorenz, J., and İ. Taş. 2012. "Zwei neue Anschlüsse zu hethitischen Beschwörungsritualen." KASKAL 9:45-48.

McMahon, G. 1991. The Hittite State Cult of Tutelary Deities. AS 25. Chicago: The Oriental Institute.

McMahon, G. 1995. "A Public Ritual for the Tutelary Deity of the Hunting Bag and the Heptad." In Atti del II Congresso Internazionale di Hittitologia, edited by O. Carruba, M. Giorgieri, and C. Mora, 26374. Pavia: Luculano.

Melchert, C. 1993. Cuneiform Luvian Lexicon. Lexica Anatolica 2. Chapel Hill, NC: self-published.

Melchert, C. 2010. "On Hittite mūgā(i)-." Orientalia (Nova Series) 79.2:207-15.

Miller, J. 2004. Studies in the Origins, Development and Interpretation of the Kizzuwatna Rituals. Studien zu den Boğazköy-Texten 46. Wiesbaden: Harrassowitz.

Miller, J. 2008. "Ein Ritual zur Reinigung eines Hauswesens durch eine Beschwörung an die Unterirdischen (CTH 446).” In Omina, Orakel, Rituale und Beschwörungen, edited by B. Janowski and G. Wilhelm, 206-17. Texte aus der Umwelt des Alten Testaments, Neue Folge 4. Gütersloh: Gütersloher Verlagshaus.

Mouton, A. 2007. Rêves hittites: Contribution à une histoire et une anthropologie du rêve en Anatolie ancienne. Culture and History of the Ancient Near East 28. Leiden/Boston/Köln: Brill.

Mouton, A. 2008a. “'Dead of Night' in Anatolia: Hittite Night Rituals.” Religion Compass 2.1:1-17.

Mouton, A. 2008b. Les rituels de naissance kizzuwatniens: un exemple de rite de passage en Anatolie bittite. Études d'archéologie et d'histoire ancienne. Paris: de Boccard.

Mouton, A. 2013. "Le rituel d'Alli d'Arzawa contre un ensorcellement (CTH 402): une nouvelle edition." In Beyond Hatti: A Tribute to Gary Beckman, edited by B.J. Collins and P. Michalowski, 195-229. Atlanta: Lockwood.

Mouton, A. 2016. Rites, mythes et prières hittites. Textes édités, traduits et présentés par Alice Mouton. Littératures anciennes du Proche-Orient 21. Paris: Les Éditions du Cerf.

Neu, E. 1968. Interpretation der hethitischen mediopassiven Verbalformen. Studien zu den BoğazköyTexten 5. Wiesbaden: Harrassowitz.

Neu, E. 1980. Studien zum endungslosen "Lokativ" des Hethitischen. Innsbrucker Beiträge zur Sprachwissenschaft 23. Innsbruck: Inst. f. Sprachwissenschaft d. Univ. Innsbruck.

Neu, E. 1996. Das hurritische Epos der Freilassung I. Untersuchungen zu einem burritisch-bethitischen Textensemble aus Hattuša. Studien zu den Boğazköy-Texten 32. Wiesbaden: Harrassowitz. 
Oettinger, N. 1979. Die Stammbildung des hethitischen Verbums. Dresdner Beiträge zur Hethitologie 7. Nürnberg: Carl Winter.

Oettinger, N. 2004. "Enstehung von Mythos aus Ritual. Das Beispiel des hethitischen Textes CTH 390A." In Offizielle Religion, lokale Kulte und individuelle Religiosität, edited by M. Hutter and S. HutterBraunsar, 347-56. AOAT 318. Münster: Ugarit.

Otten, H. 1958. Hethitische Totenrituale. Deutsche Akademie der Wissenschaften zu Berlin. Institut für Orientforschung 37. Berlin: Akademie Verlag.

Otten, H. 1961. "Eine Beschwörung der Unterirdischen aus Boğazköy." ZA 54:114-57.

Popko, M. 1995. Religions of Asia Minor. Warsaw: Academic Publications.

Rieken, E. 1999. Untersuchungen zur nominalen Stammbildung des Hethitischen. Studien zu den Boğazköy-Texten 44. Wiesbaden: Harrassowitz.

Schwemer, D. 1995. "Das alttestamentliche Doppelritual 'lwt wšlmym im Horizont der hurritischen Opfertermini ambašši und keldi." Studies in the Civilization and Culture of Nuzi and the Hurrians 7:81-116.

Siegelová, J. 1986. Hethitische Verwaltungspraxis im Lichte der Wirtschafts- und Inventardokumente. Prag: Národní muzeum v Praze.

Singer, I. 2002. Hittite Prayers. Society of Biblical Literature: Writings from the Ancient World 11. Atlanta, GA: Society of Biblical Literature.

Sommer, F., and H. Ehelolf. 1924. Das hethitische Ritual des Pāpanikri von Komana: (KBo V 1=Bo 2001): Text, Übersetzungsversuch, Erläuterungen. Boghazköi-Studien 10. Leipzig: Hinrichs.

Starke, F. 1985. Die keilschrift-luwischen Texte in Umschrift. Studien zu den Boğazköy-Texten 30. Wiesbaden: Harrassowitz.

Stefanini, R. 1983. Review of The Hittite Dictionary of the Oriental Institute of the University of Chicago (CHD). Vol. 3, fasc. 1, from la-/lai- to -ma, by H.G. Güterbock and H.A. Hoffner. Jr. JNES 42:148-49.

Steitler, C. 2017. The Solar Deities of Bronze Age Anatolia Studies in Texts of the Early Hittite Kingdom. Studien zu den Boğazköy-Texten 62. Wiesbaden: Harrassowitz.

Strauß, R. 2006. Reinigungsrituale aus Kizzuwatna. Ein Beitrag zur Erforschung hethitischer Ritualtradition und Kulturgeschichte. Berlin: De Gruyter.

Szabó, G. 1971. Ein Hethitisches Entsühnungsritual für das Königspaar Tuthaliia und Nikalmati. Texte der Hethiter 1. Heidelberg: Carl Winter.

Taracha, P. 2000. Ersetzen und Entsühnen. Das mittelhethitische Ersatzritual für den Großkönig Tuthalija (CTH*448.4) und verwandte Texte. Culture and History of the Ancient Near East 5. Leiden/ Boston/Köln: Brill.

Taracha, P. 2009. Religions of Second Millennium Anatolia. Dresdner Beiträge Hethitologie 27. Wiesbaden: Harrassowitz.

Torri, G. 2003. La Similitudine nella magia analogica Ittita. Studia Asiana 2. Rome: Herder.

Torri G., and F. Barsacchi. 2018. Hethitische Texte in Transkription: KBo 12. Dresdner Beiträge Hethitologie 50. Wiesbaden: Harrassowitz.

Trabazo, J.V.G. 2002. Textos Religiosos Hititas. Biblioteca de Ciencias Biblicas y Orientales 6. Madrid: Editorial Trotta.

Trabazo, J.V.G. 2010. "CTH 419, Ritual de Sustitución Real Edición Crítica y Traducción.” Historiae 7:38-39.

Trameri, A. 2012. "Il rituale ittita di purificazione CTH 446: Uno scongiuro degli "Antichi Dei" e delle divinità infere. Edizione critica, traduzione, commento.” Master's Thesis, Università degli Studi di Pavia. 
Trémouille, M.C. 1996a. "Un objet cultuel: le šehelliški." SMEA 38:73-94.

Trémouille, M.C. 1996b. "Une "fête du mois" pour Teššub et Hुebat." SMEA 37:79-104.

Trémouille, M.C. 2004. "I rituali magici ittiti." Res Antiquae 1:157-203.

Ünal, A. 1988. "The Role of Magic in the Ancient Anatolian Religions according to the Cuneiform Texts from Boğazköy-Hattuša." In Essays on Anatolian Studies in the Second Millenium B.C. (BMECCJ 3), edited by H.I.H.T. Mikasa, 52-85. Wiesbaden: Harrassowitz.

Van den Hout, T. 2002. "Tombs and Memorials: The (Divine) Stone House and Hegur Reconsidered." In Recent Developments in Hittite Archaeology and History: Papers in Memory of Hans G. Güterbock, edited by K.A. Yener and H.A. Hoffner Jr., 73-91. Winona Lake, IN: Eisenbrauns.

Van Gessel, B.H.L. 1998. Onomasticon of the Hittite Pantheon 1. Handbook of Oriental Studies. Section 1 The Near and Middle East 33. Leiden/New York/Köln: Brill.

Wegner, I. 1981. Gestalt und Kult der Ištar-Šawuška in Kleinasien. AOAT 36. Vluyn: Butzon \& Bercker.

Wegner, I. 2000. Hurritisch. Eine Einführung. Wiesbaden: Harrassowitz.

Wegner, I. 2007. Hurritisch. Eine Einführung 2., überarbeitete Auflage. Wiesbaden: Harrassowitz.

Makale Geliş / Received : 18.07.2019

Makale Kabul / Accepted : 17.03.2020 
